\title{
Seawater temperature and carbon isotope variations in belemnites linked to mass extinction during the Toarcian (Early Jurassic) in Central and Northern Spain. Comparison with other European sections
}

\author{
J.J. Gómez ${ }^{\mathrm{a}, *}$, A. Goy ${ }^{\mathrm{b}}$, M.L. Canales ${ }^{\mathrm{b}}$ \\ ${ }^{a}$ Dpto. de Estratigrafia. Facultad de Ciencias Geologicas TCM e Instituto de Geologia Económica (CSTC UCMj.28040 Madrid, Spain \\ b Dpto. de Paleontologia, Facultad de Ciencias Geológicas (UCM) e Instituto de Geología Económica (CSIC-UCM).28040 Madrid, Spain
}

\begin{abstract}
The Early Toarcian mass extinction marks one of the critical events in the history of the Earth. Many of these events have been linked to important climate changes. Two sections of the Toarcian showing high-resolution ammonite-based biostratigraphy are studied in Central and Northern Spain. Stable isotope datasets, based on the analysis of 192 diagenetically screened belemnite calcite and 41 bulk carbonates, allowed the construction of $\delta^{13} \mathrm{C}$ curves and a $\dot{\delta}^{18} \mathrm{O}$-based palaeotemperature. Comparison of the extinction pattern with other sections in Europe and northem Africa shows that the Early Toarcian mass extinction boundary occurred at the Tenuicostatum-Serpentinum transition, and that the organic-rich facies linked to the Oceanic Anoxic Event and the associated negative $\delta^{13} \mathrm{C}$ excursion are diachronous.

From a latest Pliensbachian cooling interval, a first increment of seawater temperature averaging about $4.5^{\circ} \mathrm{C}$, started around the Pliensbachian-Toarcian boundary and developed during the earliest Toarcian Tenuicostatum Biochron. marking the beginning of the main extinction interval. From the Tenuicostatum-Serpentinum transition up to the Bifrons Biochron, a rise in seawater tempcrature averaging $5.7{ }^{\circ} \mathrm{C}$ to $7.8^{\circ} \mathrm{C}$ was recorded. This warming interval, which started rapidly and which seems to be synchronous at least in Western liurope is considered one of the main factors responsible for mass extinction. For some authors this rapid warming was probably due to a massive injection of greenhouse gases into the atmosphere, but it does not seem to be recorded in belemnite calcite, and the origin of these possible gases is largely debated in the literature.

Additional isotope excursions were found in the studied sections in Spain during the Middle and Late Toarcian. A negative $\delta^{13} \mathrm{C}_{\mathrm{bel}}$ excursion has been recorded at the latest Bifrons Biochron. Above this shift, the Illustris-Vitiosa subzones thermal peak, which represens a $2-3{ }^{\circ} \mathrm{C} \Delta T$, could be linked to one of the tectonomagmatic activity peaks recorded in the Karoo Basin. A renewal in the ammonite and brachipod faunas coincident with this climatic change has been recognized in NW Europe and Western Tethys.

An interesting thermal peak has also been detected in belemnites of the Insigne Subzone. $\Delta T$ is in the order of $3{ }^{\circ} \mathrm{C}$, and in both sections the thermal peak is included into a $\delta^{13} C_{\text {bel }}$ negative excursion of about $-1.5 \%$. Relative synchrony with the new age for the Karoo main magmatic activity $\left(178-180 \mathrm{Ma}\right.$ ) indicates that the $\delta^{13} \mathrm{C}$ negative anomaly and the warming interval could be caused by the release of volcanogenic grcenhousc gases. At this short interval, noteworthy changes in the abundance and diversity
\end{abstract}

\footnotetext{
* Corresponding author. Tel.: +34 913944783; fax: +34 913944808.

E-mail addresses: jgomez@geo.ucm.es (J.J. Gómez), angoy@geo.ucm.es (A. Goy), mcanales@geo.ucm.es (M.L. Canales).
} 
of the recorded assemblages in several faunal groups of NW Europe and Tethys are observed. The uppermost Levesquei Subzone thermal peak has only been recognized in the deposits of the section located in Central Spain and coincides with a positive $\delta^{13} \mathrm{C}$ excursion.

Keywords: Jurassic; Stable isotope; Palaeotemperature; Mass extinction; Climate change

\section{Introduction}

Mass extinctions represent critical peaks in the loss of biodiversity, which could be linked to climate. The Lower Jurassic Toarcian stage (183-175.6 Ma) represents a remarkably interesting time interval of the Earth's history, due to the evidence of a significant mass extinction event that notably affected the marine biota (e.g. Hallam, 1961, 1986, 1987; Arias et al., 1992; Little and Benton, 1995; Hallam, 1996; Aberhan and Fürsich, 1997; Harries and Little, 1999; Pálfy and Smith, 2000; Cecca and Macchioni, 2004). Also during the Early Toarcian, deposition of organic-rich black shale facies has been interpreted as the result of a widely distributed major Early Toarcian Oceanic Anoxic Event (ETOAE), which has been assumed by many authors to be one of the main causes of the mass extinction (e.g. Jenkyns, 1988; Nikitenko and Shurygin, 1992; Bassoullet and Baudin, 1994; Harries and Little, 1999; Pálfy and Smith, 2000; Jenkyns et al., 2002; Vörös, 2002; Tremolada et al., 2005; Wignall et al., 2005). The ETOAE has been studied mainly in Europe, but it has been extended to many parts of the world, postulated as a synchronous event (Jenkyns, 1985; Jenkyns and Clayton, 1986; Jenkyns, 1988; Jenkyns et al., 1994; Jiménez et al., 1996; Jenkyns and Clayton, 1997; Jenkyns, 1999; Jenkyns et al., 2001, 2002; Jenkyns, 2003; Mailliot et al., 2006). However, reappraisal through high-resolution stratigraphy indicates that deposition of the organic-rich facies, linked by many authors to the ETOAE is diachronous, at the ammonite zone/subzone level, and for some authors only partly coincident with the mass extinction event (Wignall et al., 2005).

During Early Toarcian, major perturbations in the carbon cycle have been reported. One of the most important anomalies is marked by an up to $8 \%$ negative $\delta^{13} \mathrm{C}$ excursion, recorded in bulk rock carbonates, in marine organic matter, and in wood, in samples from several European localities, which generally contain black shale facies (Küspert, 1982; Jenkyns and Clayton, 1986; Jiménez et al., 1996; Schouten et al., 2000; Hesselbo et al., 2000).

Strong variations in the temperature of the oceans have been reported, mainly for the Early Toarcian (Jenkyns et al., 1991; Chandler et al., 1992; Sælen et al., 1996; McArthur et al., 2000; Röhl et al., 2001; Schmid-Röhl et al., 2002; Rosales et al., 2003; Jenkyns, 2003; Rosales et al., 2004), as well as major transgressive events (Hallam, 1961, 1988, 1992; Bassoullet et al., 1993; Hallam, 1996, 1997; de Graciansky et al., 1998; Gómez and Goy, 2000, 2005).

Possible causes of Early Toarcian mass extinction are also debated in literature. The interpretation of the negative $\delta{ }^{13} \mathrm{C}$ excursion as a consequence of a rapid release of biogenic methane gas-hydrate to the ocean and the atmosphere and their subsequent warming has been defended by Hesselbo et al. (2000), Beerling et al. (2002), Kemp et al. (2005) and Hesselbo et al. (2007a). However, van de Schootbrugge et al. (2005a) conclude that the Early Toarcian negative $\delta^{13} \mathrm{C}$ carbon shift is the result of a combination of restriction on circulation and local density stratification. Nevertheless, some authors have argued against upwelling-derived isotopic signature based on organic geochemical evidence (van Breuguel et al., 2006). Other authors attempt to establish a close relationship between the Early Jurassic extinction and the ETOAE with the Karoo-Ferrar flood basalt volcanism (southern Africa, Antarctica, Australia and New Zealand), based on their supposed synchronism (Pálfy and Smith, 2000; Svensen et al., 2007). This correlation has been discussed by Jourdan et al. $(2004,2005)$, on the basis of previous and new ${ }^{40} \mathrm{Ar} /{ }^{39} \mathrm{Ar}$ age data. McElwain et al. (2005) conclude that the carbon dioxide changes can be best explained by the release of themogenic methane due to the intrusion of Gondwana coals by Toarcian dolerites of the Karoo-Ferrar magmatic province. However, the ages obtained for the main Karoo tectonomagmatic events (Jourdan et al., 2005) do not seem to match with the age of the negative $\delta^{13} \mathrm{C}$ excursion. Finally, Kemp et al. (2005) propose that the warming induced by the release of methane is the main cause of mass extinction.

More data based on high-resolution stratigraphy are needed to contribute to the elucidation of the numerous problems concerning the Early Toarcian mass extinction. The attainment of detailed records of the whole Toarcian palaeotemperatures and of carbon isotope evolution are also considered of interest, in order to analyze the local to 
global climate variations that occurred after the main extinction event, and to detect additional younger climate changes and possible links with other biotic crisis.

Here we present the results of the study of two particularly well exposed Toarcian sections, the RodilesSanta Mera section, located in Northern Spain (Fig. 1a, b) and the La Almunia-Ricla section of carbonates, located in Central Spain (Fig. 1a, c). In both sections detailed ammonite-based biostratigraphy, coupled with stable isotope analysis of belemnite calcite and bulk carbonates have been performed.

\section{Materials and methods}

The sections have been studied bed by bed. Ammonites were collected and used for biostratigraphical purposes and the belemnites and rocks were prepared for facies, isotopic and geochemical studies. A total of 208 belemnite rostra were collected in the 308 beds of the Rodiles-Santa Mera section, and 101 analysis of stable isotope were performed, to obtain the primary stable isotopes signal of the Toarcian seawater. In addition, a total of 41 bulk rock samples were also collected and analyzed for $\mathrm{C}$ and $\mathrm{O}$ isotope, and 30 samples were analyzed for total organic carbon (TOC). In the La Almunia-Ricla section, 92 belemnites from the 369 beds were collected and 91 analyses performed. The natural gamma ray emissions of the sediments were measured bed by bed with a portable scintillation counter.

It has been recognized by many authors that belemnite rostra are one of the best archives of the primary geochemical signal of the oceans (e. g. Sælen and Karstang, 1988; Sælen, 1989; Sælen et al., 1996; Podlaha et al., 1998; McArthur et al., 2000; Rosales et al., 2001a,b; Bailey et al., 2003; Jenkyns, 2003; Rosales et al., 2003, 2004; van de Schootbrugge et al., 2005a; McArthur et al., 2007). Measurements of $\delta^{18} \mathrm{O}$ values performed on diagenetically screened belemnite rostra have been considered as one of the most reliable tools to be used as a proxy for calculation of seawater palaeotemperatures. Values obtained in the Spanish sections have been used here for this purpose.

For the assessment of possible burial diagenetic alteration of the collected belemnites, polished samples and thick sections of each belemnite rostra were prepared. Thick sections were studied under the petrographic microscope and cathodoluminescence (Fig. 2). Many of the studied belemnite rostra were non-luminescent, except

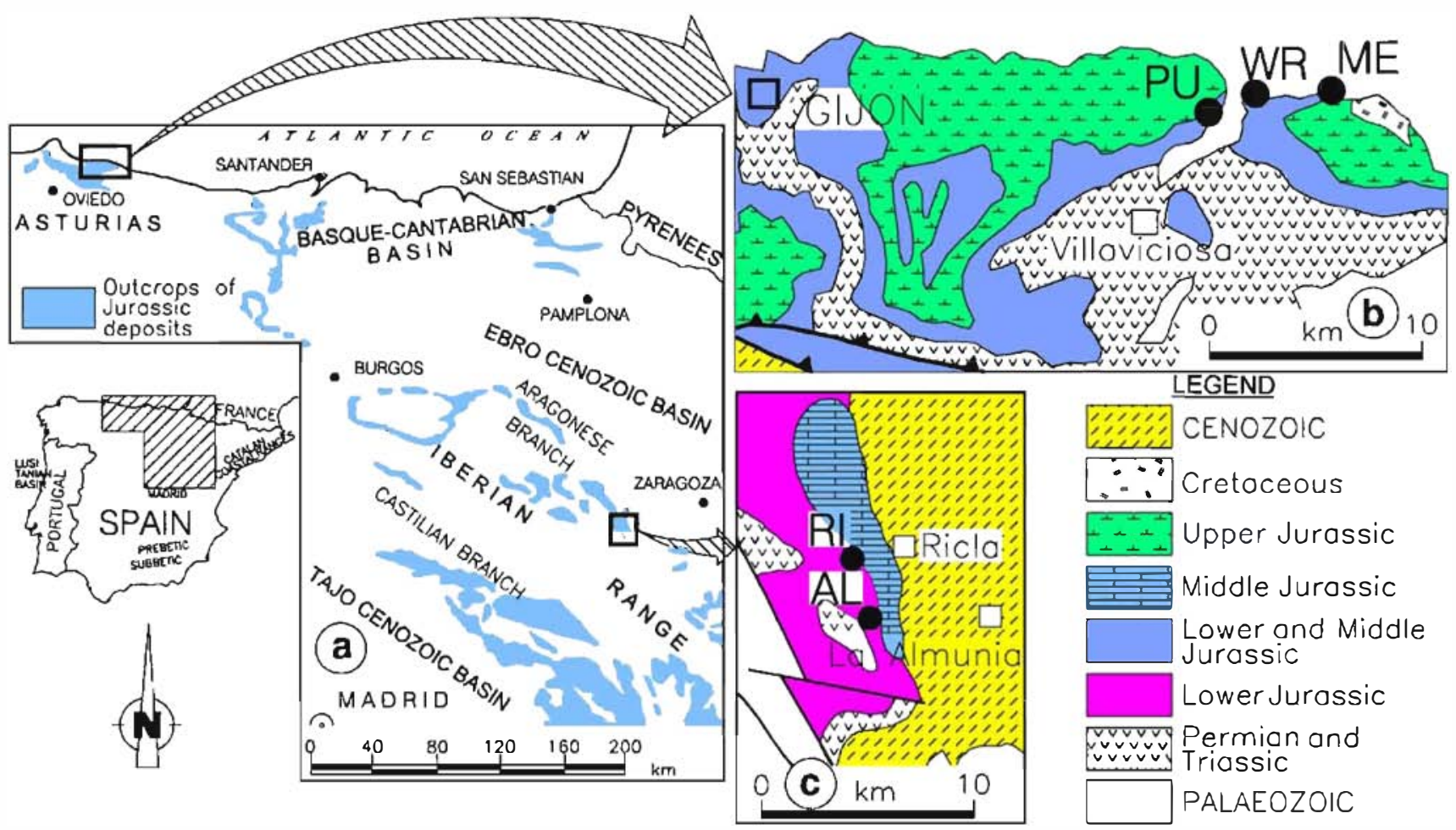

Fig. 1. Location of the studied sections. (a) Map showing the outcrops of the Jurassic deposits in Northem and Central Spain and the location of the Rodiles-Santa Mera section (Asturias province) and the La Almunia-Ricla section, placed in the Iberian Range. (b) Geological sketch of the area containing the Rodiles (WR) and Santa Mera (ME) sections. The El Puntal section (PU) has been used as a complementary section. (c) Geological sketch of the area that contains the La Almunia (AL) and the Ricla (RI) sections. 

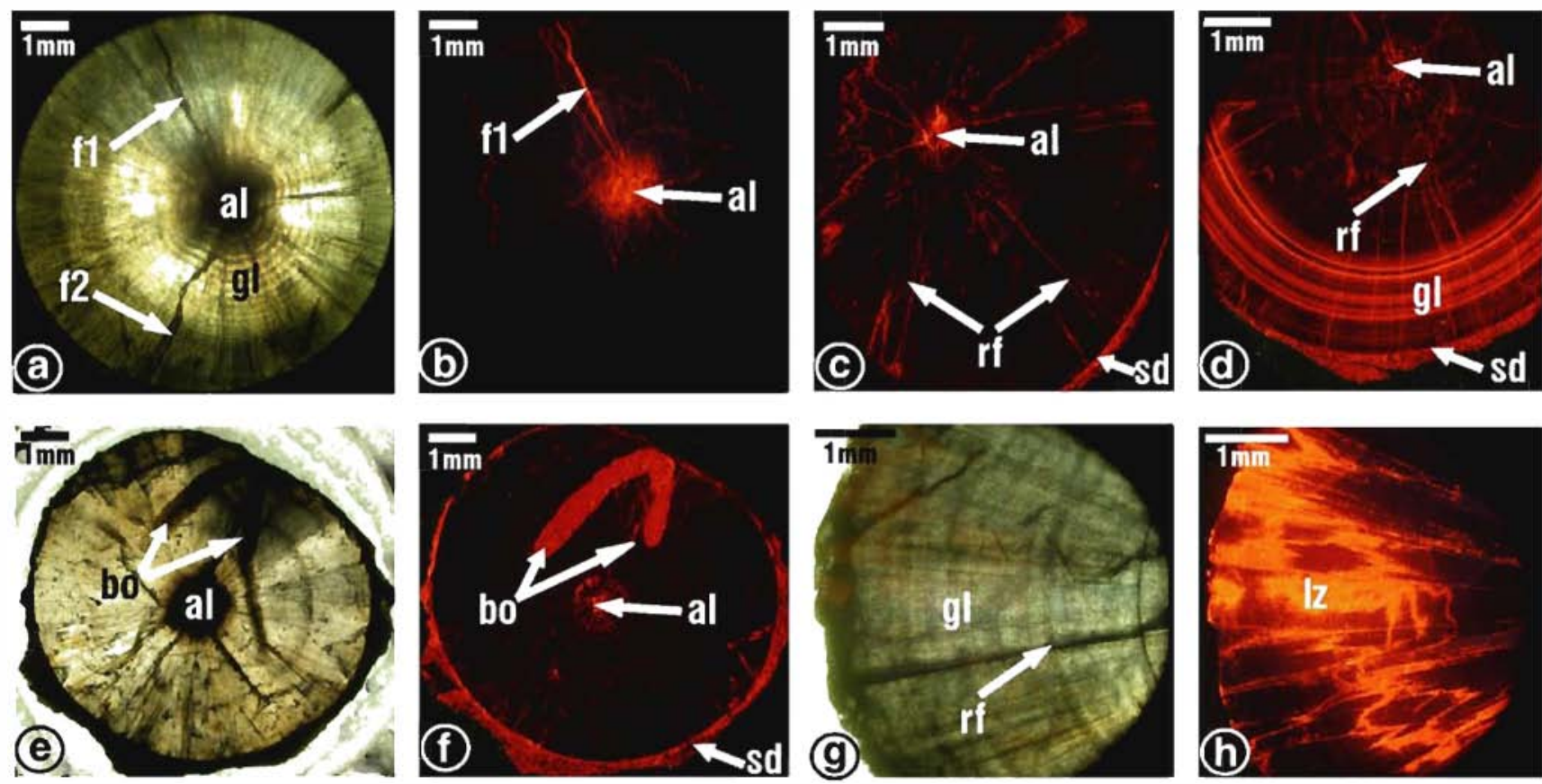

Fig. 2. Photomicrographs of belemnite rostra from the Toarcian of the Rodiles-Santa Mera and the La Almunia-Ricla sections. (a) Well-preserved belemnite under polarized light, showing radial fractures ( $\mathrm{fl}$ and $\mathrm{f2}$ ), apical line (al) and growthlayers (gl). (b) Same specimen of belemnite as (a). Luminescence is only present in the fracture (f1) and in the apical line (al), indicating the absence of diagenetic cements in most of the rostra. Sample (a) and (b) from layer 15 (Early Toarcian, Tenuicostatum Zone, Paltum Subzone) of the La Almunia-Ricla section. (c) Belemnite rostra under cathodoluminescence showing luminescent diagenetic cements in thin radial fractures (rf) and stylolites, in the apical line (al) and in the outer carbonate sediment attached to the rostra (sd). Sample from the layer 83 of the Santa Mera section (Upper Toarcian, Dispansum Zone, Insigne Subzone). (d) Example of belemnite rostra showing luminescent diagenetic cement in the apical line (al), in the radial fractures (rf), in the growthlayers (gl) and in the phragmocone wall and the carbonate sediment attached to the specimen (sd). Sample from the layer 61 of the Rodiles section (Early Toarcian, Serpentinum Zone, Falciferum Subzone). (e) Belemnite rostra under polarized light, showing apical line (al) and microborings (bo). (f) Same specimen as (e) under cathodoluminescence, showing luminescence in the microboring fillings (bo), in the apical line (al) and in the phragmocone wall and the attached carbonate sediment (sd). Belemnite (e) and (f) from the layer 33 of the Santa Mera section (Upper Toarcian, Variabilis Zone, Variabilis Subzone). (g) Photomicrograph of belernnite rostra under polarized light, showing radial fractures ( $\mathrm{rf}$ ) and growthlayers (gl). (h) Same belemnite as (g) under cathodoluminescence, showing the presence of radial and irregular luminescent diagenetic cement, fractures and stylolites (lz). Samples showing this degree of diagenesis have been refused for sampling and analysis. Belemnites (g) and (h) were collected in the layer 123 of the Santa Mera section (Upper Toarcian, Dispansum Zone, Insigne Subzone).

for the apical line and the outer phragmocone wall, which were frequently luminescent and consequently sampling of these parts was avoided. The belemnite guards have been mapped and/or microphotographed and only the nonluminescent portions were sampled using a microscopemounted dental drill. Additionally, 30 belemnite calcite samples were analyzed using X-ray diffraction techniques to make sure that no other minerals except for calcite were present in the samples. A first pass sampling was analyzed for stable isotopes in the Salamanca University (Spain) and the remaining belemnite and bulk rock samples in Michigan University (USA). Several samples were analyzed in both laboratories with acceptable repeatability. In all samples, isotope ratios are reported in per mil with respect to the standard Peedee belemnite (PDB). A total of 51 analyses were duplicated and 32 samples of standard were analyzed. Analytical error was in most cases better than $\pm 0.1 \%$ on both carbon and oxygen. TOC analyses have been performed in the Centro de Espectrometría Atómica of the Universidad Complutense in Madrid.

\section{The Toarcian succession in the Rodiles-Santa Mera section}

Toarcian deposits, which are exceptionally well exposed along the coastal cliffs of the Eastern part of Asturias in Northern Spain (Fig. 1a, b), are represented by a nearly $45 \mathrm{~m}$ thick succession of altemating lime mudstone and marls (Fig. 3), belonging to the Santa Mera Member of the Rodiles Formation (Valenzuela, 1988). The succession has been studied in two sections, the Rodiles section, where the Upper Pliensbachian-Lower Toarcian deposits crop out, and the Santa Mera section, where the Middle-Upper Toarcian, Aalenian and part of the Bajocian sediments are exposed. For the Lower Toarcian deposits, the El Puntal section (Fig. lb) has been used as a complementary 
outcrop. Continuity of most of the beds allows correlation bed by bed throughout the different localities.

\subsection{Biostratigraphical subdivisions}

Ammonite-based biostratigraphical subdivisions of the Asturian Toarcian deposits have been carried out by Suárez-Vega (1974) and Goy et al. (1997). The biostratigraphical data presented here are based on our own ammonites collection and determination carried out during the last ten years, which allows subdivisions at the subzone scale (Fig. 3). The obtained zonation has been compared and correlated with the standard scales proposed by Dean et al. (1961), Elmi et al. (1989, 1994, 1997), Macchioni (2002) and Page (2003, 2004). The ammonite succession shows a high proportion of common taxa with the UK sections, allowing high-resolution correlation between both areas.

\subsection{Sequence stratigraphy}

Sequence stratigraphy of the Toarcian deposits in Central and Northem Spain has been studied by Gómez and Goy (2000, 2005), Aurell et al. (2003), and Quesada et al. (2005). According to Gómez and Goy $(2000,2005)$, a number of Upper Pliensbachian-Upper Toarcian sequence cycles can be observed (Fig. 4). The main peaks of transgressions, marked by the change between the deepening to the shallowing sets of parasequences (Fig. 3), have been identified in the Semicelatum Subzone, in the Tenuicostatum-Serpentinum zonal boundary, coinciding with the maximum development of black shale facies, in the Bifrons Zone and near the DispansumPseudoradiosa zonal boundary. The top of the cycle in Asturias is marked by a discontinuity with an associated sedimentary hiatus that affects the deposits of the uppermost Toarcian and the lowermost Aalenian.

\subsection{Stable isotope records}

Profiles of the obtained values of $\delta^{13} \mathrm{C}_{\mathrm{bel}}, \delta^{18} \mathrm{O}_{\mathrm{bel}}$ and $\delta^{13} \mathrm{C}_{\text {carb }}$ plotted against the stratigraphic levels of the Rodiles-Santa Mera section are shown in Fig. 3, and a cross-plot of the values of $\delta^{13} \mathrm{C}_{\text {bel }}$ against $\delta^{18} \mathrm{O}_{\text {bel }}$ is shown in Fig. 5.

An increase in the $\delta^{13} C_{\text {bel }}$ values at the Semicelatum, Elegantulum and early Falciferum biochrons is notable. The peak value $(3.2 \%)$, recorded in belemnites of the Elegantulum Subzone, is located slightly above the main occurrence of black shale facies. From this point and above, the overall $\delta^{13} \mathrm{C}_{\text {bel }}$ values generally tend to decrease through Middle and Late Toarcian. Two minor negative $\delta^{13} \mathrm{C}_{\text {bel }}$ excursions are recorded during the Middle and Late Toarcian. The older excursion is recorded in the Middle Toarcian Bifrons Biochron. The younger negative excursion (several negative values of up to $-0.86 \%$ ) develops at the Thouarsense-Dispansum transition.

The $\delta^{13} \mathrm{C}_{\text {carb }}$ curve obtained from the bulk carbonate samples shows a significant $1.5 \%$ o negative excursion recorded around the boundary between the Tenuicostatum and the Serpentinum zones, coinciding with the occurrence of black shale facies.

Considering the $\delta^{18} \mathrm{O}_{\text {bel }}$ curve at the top of bed 43.3 (Tenuicostatum-Serpentinum zonal boundary), a clear excursion towards more negative values can be tested. The anomaly reaches several peak values of around $-2.9 \%$ in the Elegantulum Biochron, and extends up to the Bifrons Biochron. Other negative $\delta^{18} \mathrm{O}_{\text {bel }}$ peaks are recorded in the belemnites of the Illustris-Vitiosa subzones of the Variabilis Zone and in the lowermost Dispansum Zone (Insigne Subzone), coinciding with a negative $\delta^{13} \mathrm{C}_{\text {bel }}$ excursion.

\subsection{Black shale facies}

Black shale facies in the Rodiles-Santa Mera section, with TOC values commonly higher than $0.5 \mathrm{wt} . \%$, are recorded from bed 21 to bed 43.2 (Fig. 6a), but the most significant TOC values, above $1 \mathrm{wt} \%$, are recorded in beds 43.2, 43.5 and 43.6 (Fig. 6a, b). Within the black shale facies, a distinctive interval showing microlaminations (beds 43.4 and 43.5) can be observed (Fig. 6b, c). Inside the microlaminated unit, based on the FOD of Hildaites wrighti, the boundary between the Tenuicostatum and the Serpentinum zones has been located. This microlaminated unit corresponds to the peak transgression

Fig. 3. Stratigraphic column of the Rodiles-Santa Mera section. Sequence stratigraphy has been based on lithological, palaeontological and palaeoecological observations and supported by gamma-ray field measurements. For the ammonite-based biostratigraphy, only the distribution of the most significant species useful for the definition of the zones and subzones has been included. Stable isotope $\delta^{18} \mathrm{O}_{\text {bel }}$ and $\delta^{13} \mathrm{C}_{\mathrm{bel}}$ curves of the $\mathrm{Upper}$ Pliensbachian and the Toarcian were obtained from belemnite calcite (squares). The $\delta^{13} \mathrm{C}_{\text {carb }}$ curve of the Upper Pliensbachian-Middle Toarcian (hexagons) was obtained from bulk carbonate. Zones abbreviations: TENUICOS-Tenuicostatum. THO-Thouarsense. PSE-Pseudoradiosa. AALAalensis. OPA-Opalinum. Subzones abbreviations: AP-Apyrenum. HA-Hawskerense. PA-Paltum. SE-Semicelatum. VI-Vitiosa. BI-Bingmanni. TH-Thouarsense. FS-Fascigerum. FA-Fallaciosum. GR-Gruneri. LE-Levesquei. PS-Pseudoradiosa. MA-Mactra. AA-Aalensis. CO-Comptum. 


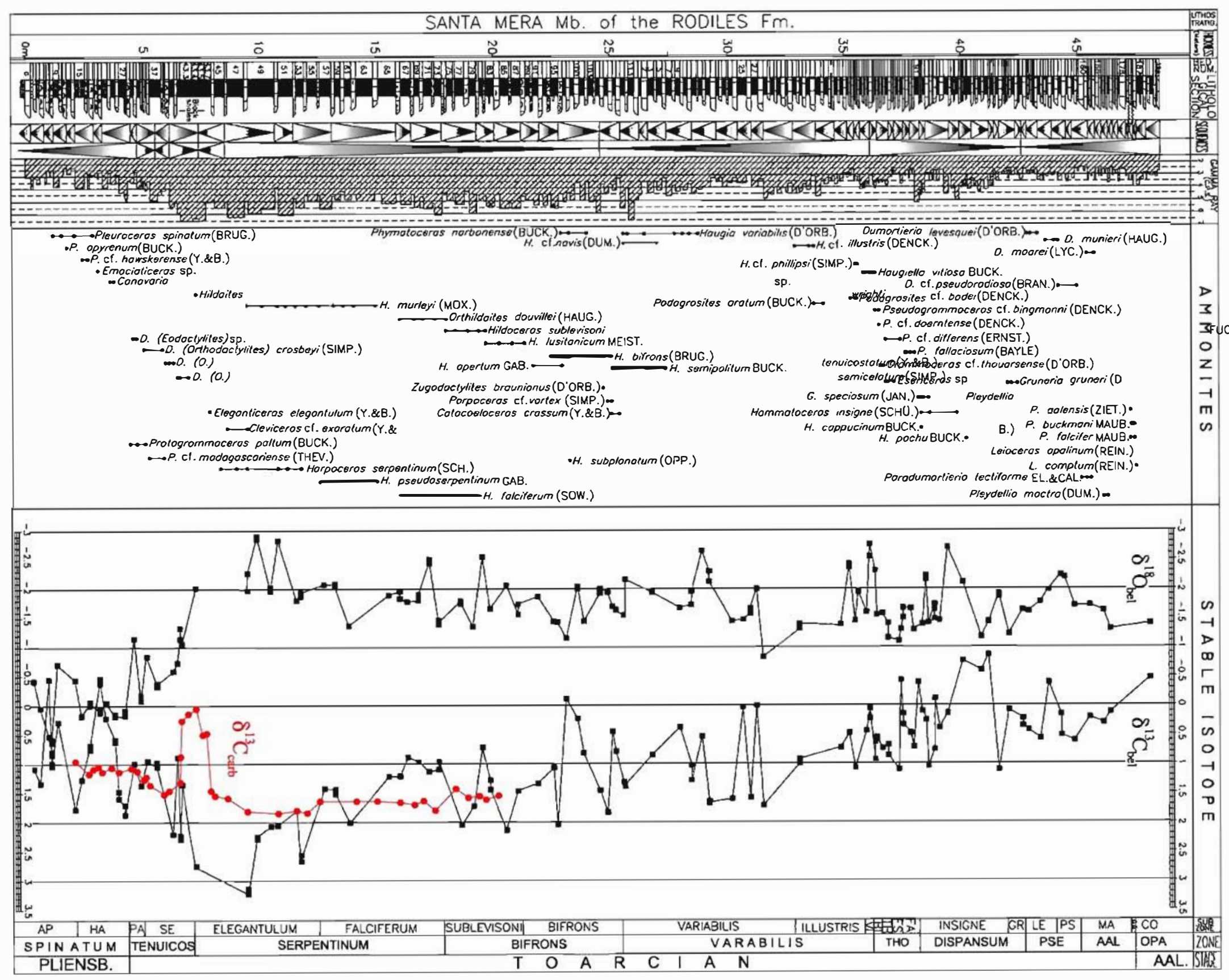

E. 告 虽

ธี च

茨寻. 志

唨 少

2. 2

3. $\frac{2}{2}$

용

硧虰

․ㅡㅇ

F

ᄃ

자음

วิ용

Ш艹

ㄱ. 응

$5 \%$

ซั

的

23

顿

艺芯

\& 0

의 응

总总

ڤ

공요

递

官

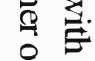

品

官.

롱 矛

定 
4. The Toarcian succession in the La Almunia-Ricla section

One of the finest Toarcian ammonite successions in Europe has been described in the $70 \mathrm{~m}$ thick La AlmuniaRicla expanded section (Fig. 1a, c), by Goy and Martínez (1990) and Goy et al. (1996). The Lower and Middle Toarcian deposits are well exposed along a hillside near the La Almuniatown, and the Middle and Upper Toarcian deposits occur in a railway cutting near Ricla. The lowermost part of the Toarcian is represented by bioclastic wackestones to packstones of the Barahona Fm, but most of the Toarcian is represented by the hemipelagic alternating lime mudstone and marls of the Turmiel Fm, except for the uppermost part of the section, which is represented by the carbonates of the Casinos Fm (Fig. 7). No black shale facies are present in this section, where the TOC rarely reaches values of $0.9 \mathrm{wt} . \%$. However, mass extinction is evidenced by the progressive disappearance of the benthic fossils at the Tenuicostatum Biochron.

\subsection{Biostratigraphical subdivisions}

A detailed ammonite-based subdivision at the scale of subzone has been carried out and represented in Fig. 7, where the distribution of the species characterizing the subzones boundaries has been represented. The identified ammonite succession shows notable similarities with the succession of the NW Europe province, but also includes several taxa common in the Mediterranean domain, such as Dactylioceras (Eodactylites) in the Tenuicostaum Zone, Merlaites in the Variabilis Zone and Geczyceras speciosum in the Dispansum Zone.

\subsection{Sequence stratigraphy}

Lower-Middle Toarcian sequence stratigraphy recorded in the La Almunia-Ricla section is very similar to the sequence stratigraphy described for the RodilesSanta Mera section (Fig. 4). In both cases the boundary between the Tenuicostatum and the Serpentinum zones coincides with a transgressive interval.

\subsection{Stable isotope records}

The curves displaying the evolution of $\delta^{13} \mathrm{C}_{\mathrm{bel}}$ and $\delta^{18} \mathrm{O}_{\text {bel }}$ values in this section are shown in Fig. 7. A crossplot of the $\delta^{13} \mathrm{C}_{\text {bel }}$ and $\delta^{18} \mathrm{O}_{\text {bel }}$ values can be interpreted as reflecting the original marine signal with no evidence of important diagenetic overprint (Fig. 8).

Several noteworthy excursions in the $\delta^{13} \mathrm{C}_{\text {bel }}$ values are visible. Carbon isotope values averaging $1.1 \%$ in the

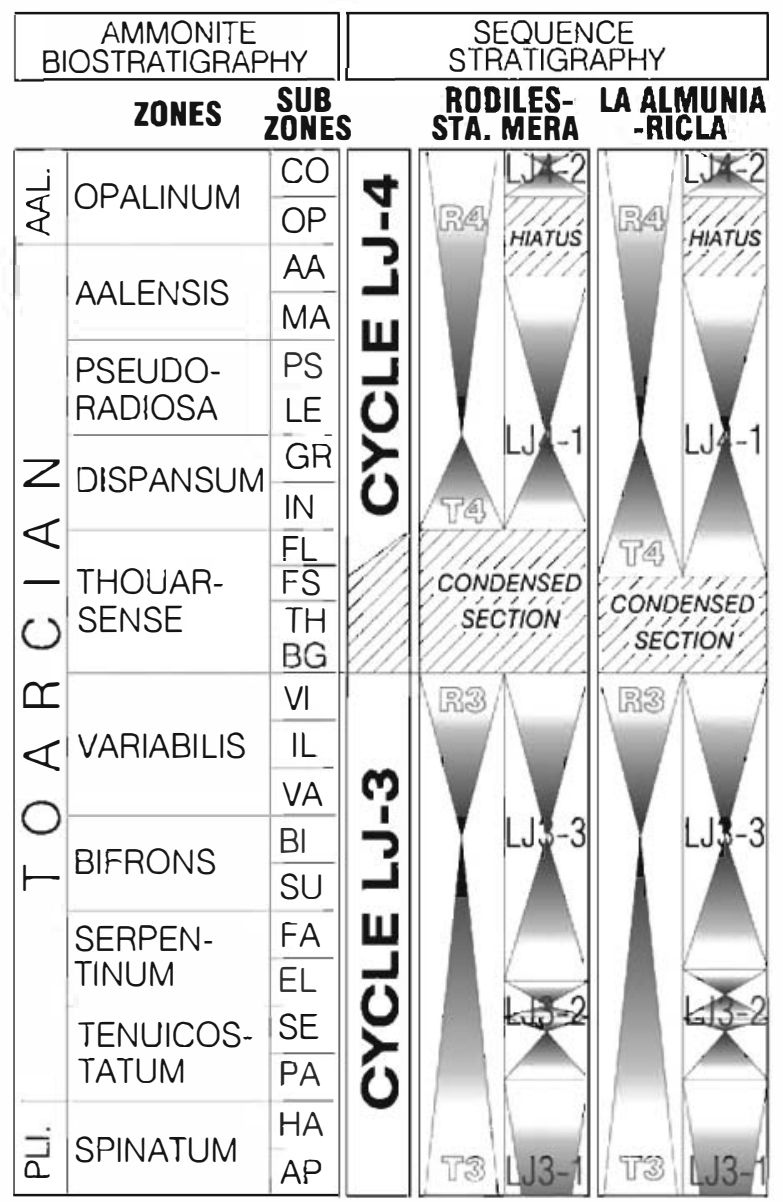

Fig. 4. Sequence stratigraphy and ammonite-based biostratigraphy of the Rodiles-Santa Mera and La Almunia-Ricla sections. Studied deposits are included in part of the transgressive-regressive facies cycles LJ-3 and LJ-4 (Gómez and Goy, 2005). Transgressive peaks in cycle LJ-3 are recorded in the deposits of the Sernicelatum Subzone and around the Tenuicostatum-Serpentinum zonal boundary (LJ3-2 Cycle). The main Toarcian transgressive peak occurs at the Bifrons Biochron. The transgressive peak in cycle LJ-4 is marked around the DispansumPseudoradiosa zonal boundary. Cycle LJ-3 is topped by condensed sections and cycle LJ-4 by a hiatus that can affect the Upper Toarcian and the Lower Aalenian deposits. Subzones abbreviations: AP-Apyrenum. HA-Hawskerense. PA-Paltum. SE-Sernicelatum. EL-Elegantulum FA-Falciferum. SU-Sublevisoni. BI-Bifrons. VA-Variabilis. IL-Illu stris. VI-Vitiosa. BG-Bingmanni. TH-Thouarsense. FS-Fascigenum. FL-Fallaciosum. IN-Insigne. GR-Gruneri. LE-Levesquei. PS-Pseudoradiosa. MA-Mactra. AA-Aalensis. OP-Opalinum. CO-Comptum.

uppermost Pliensbachian and the lowest Toarcian (Tenuicostatum Zone, Paltum Subzone) record a significant increase (average values of $2.1 \%$, including peak values of up to $3.1 \%$ ) at the Semicelatum Biochron and in the Elegantulum and part of the Falciferum biochrons.

Three minor negative $\delta^{13} C_{\text {bel }}$ peaks are recorded in the Toarcian. The lowermost negative $1.5 \%$ o peak corresponds to the latest Tenuicostatum Biochron, but no negative values were measured. The middle negative excursion is recorded in the Middle Toarcian Bifrons Zone, where values down to $-0.34 \%$ are reached. The youngest 


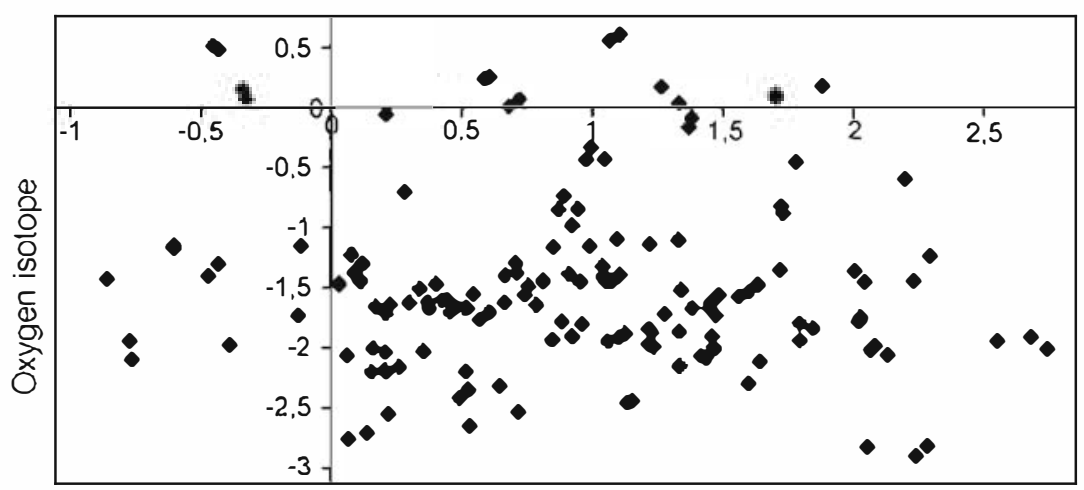

Carbon isotope

Fig. 5. Cross-plot of $\delta^{18} \mathrm{O}_{\text {bel }}$ against $\delta^{13} \mathrm{C}_{\text {bel }}$ values obtained in belemnite calcite from the Upper Pliensbachian and the Toarcian samples of the Rodiles-Santa Mera section. Most of the values are well grouped into a cluster type of distribution, suggesting that they represent the original marine signal with lack of significant diagenetic overprints.

negative excursion, having $\delta^{13} \mathrm{C}_{\text {bel }}$ negative values, occurs in the latest part of the Thouarsense Biochron and at the Dispansum Biochron. Two positive excursions have been recorded at the latest Toarcian Levesquei and the Mactra biochrons.

During the latest Pliensbachian and the earliest Toarcian (Tenuicostatum Biochron), average $\delta^{18} \mathrm{O}_{\text {bel }}$ values are around $-0.8 \%$, but from the Tenuicostatum-Serpentinum zonal boundary, a noteworthy excursion towards more negative values starts, reaching several peak values of $-3.9 \%$ from the Elegantulum Biochron up to the latest Bifrons Biochron. After this excursion, three short-term duration negative excursions are recorded. The oldest one occurs in the late Variabilis Biochron, but the most significant is recognized at the earliest Dispansum Biochron, where values of up to $-4 \%$ were obtained. The youngest

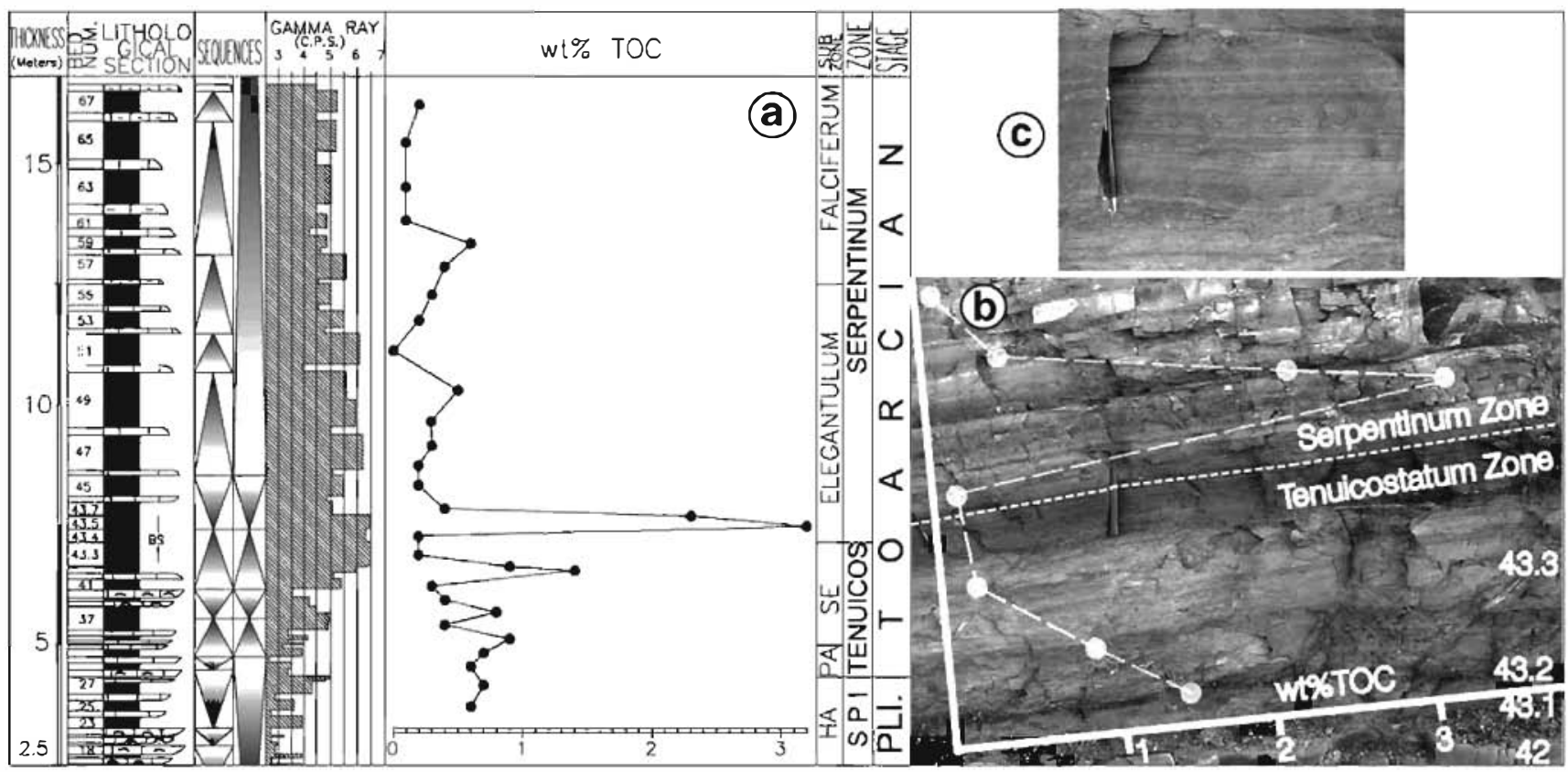

Fig. 6. Organic-rich facies of the Rodiles-Santa Mera section. (a) Stratigraphic column showing the distribution of black shale facies (BS) in beds 43.1 to 43.7. Maximum TOC values between 1.4 and $3.2 \mathrm{wt} \%$ are recorded around the Tenuicostatum-Serpentinum zonal boundary, coinciding with a transgressive peak and the maximum gamma-ray values. (b) Field photograph of the black shale interval with the TOC values represented. Notice that the thinly laminated facies contains the Tenuicostatum-Serpentinum zonal boundary. (c) Detail of the microlaminated oil shale facies. Preservation of this fine laminae indicate the absence of bioturbation due to the lack of benthic organisms, as well as the lack of important current or wave action, as commonly occurs in anoxic environments. Zones abbreviations: SPI-Spinatum. TENUICOS-Tenuicostatum. Subzones abbreviations: HA-Hawskerense. PA-Paltum. SESernicelatum 


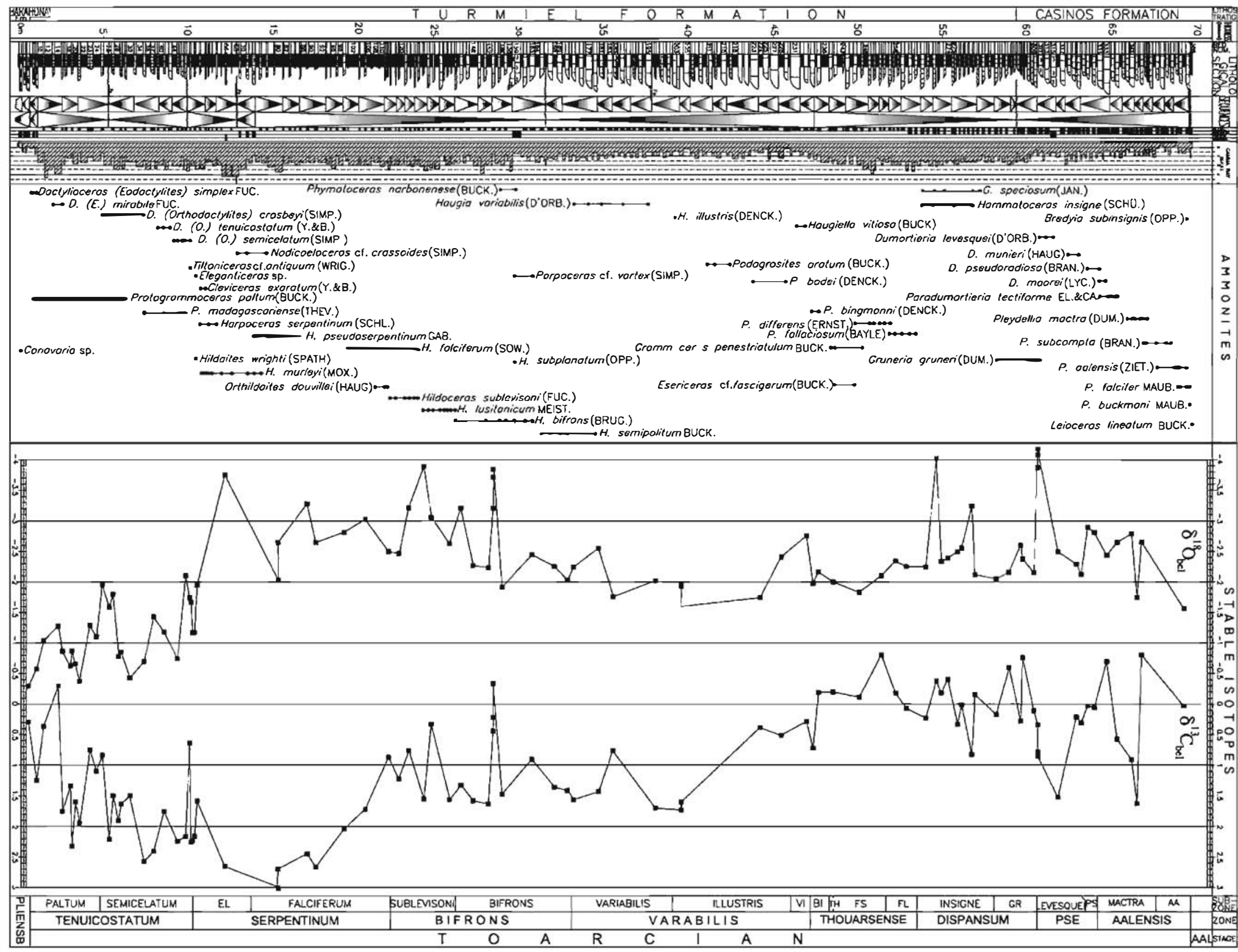




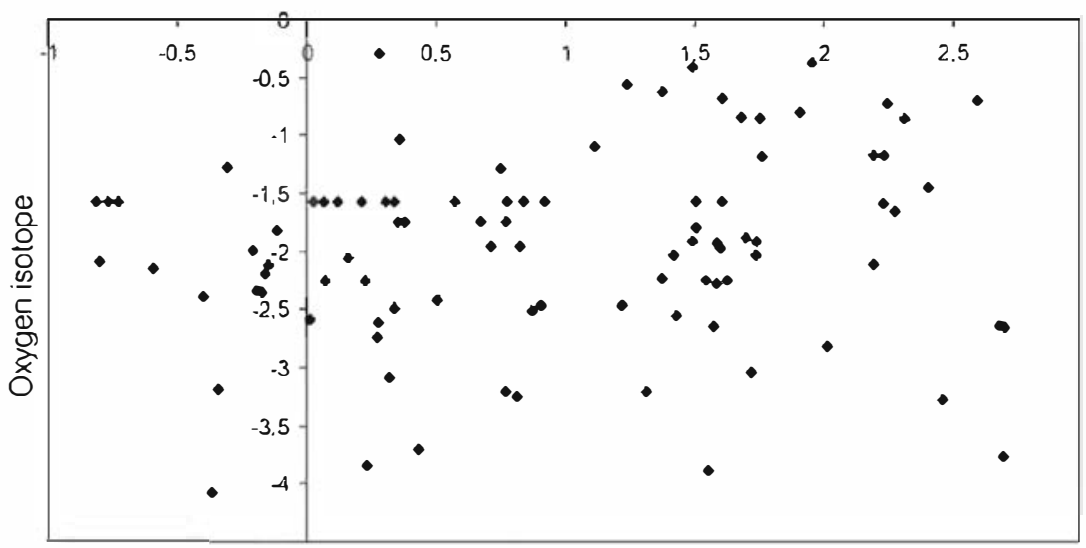

Carbon isotope

Fig. 8. Cross-plot of $\delta^{18} \mathrm{O}_{\text {bel }}$ against $\delta^{13} \mathrm{C}_{\text {bel }}$ values obtained in belemnite calcite from the Upper Pliensbachian and the Toarcian of the La AlmuniaRicla section. Most of the values are well grouped into a cluster type of distribution, suggesting that they represent the original marine signal with lack of significant diagenetic overprints.

negative excursion (up to $-4.4 \%$ ) is recorded in the Levesquei Zone.

\subsection{The Early Toarcian mass extinction record in the La Almunia-Ricla section}

A synthesis showing the stratigraphical distribution of benthic organisms during the Early Toarcian in the La Almunia-Ricla section is depicted in Fig. 9. Most of the studied groups reflect a massive extinction event at the Tenuicostatum-Serpentinum transition. Benthic organisms show a gradual loss of diversity at the Tenuicostatum Biochron, and many species disappear at or near both biochrons boundary.

Referring to the brachiopods, five species disappear near the Tenuicostatum-Serpentinum zonal boundary, with a substantial lack of representatives of this group at the lower part of the deposits of the Serpentinum Zone (Elegantulum Subzone). The appearance of Soaresirhynchia bouchardi represents the opportunistic first brachiopod colonizing the Iberian platform system. Similar results are shown by other studies carried out in several sections of the Iberian Range, where 16 species disappeared at the Tenuicostatum Biochron, 9 of which at the Tenuicostatum-Serpentinum zonal boundary (Joral and Goy, 2000). Colonization of the platform took place at the Serpentinum Biochron, when 6 more species appeared in the La Almunia-Ricla section, and 10 at the scale of the Iberian Range (Joral and Goy, 2000). Following the Kauffman and Erwin (1995) nomenclature, brachiopods clearly mark the extinction interval through the Tenuicostatum Biochron and the extinction boundary around the Tenuicostatum-Serpentinum transition (Fig. 9).

Regarding the bivalves, 7 species disappeared at the Tenuicostatum Biochron, and 2 around the TenuicostatumSerpentinum zonal boundary. At the scale of the Iberian Range, 11 species disappeared, 7 species were affected but lately recovered, and 7 species were not affected by the extinction (Gahr, 2005).

Ostracods are one of the fossil groups that better reflect the Early Toarcian mass extinction in the La AlmuniaRicla section. A total of 22 species disappeared during the extinction interval and only 4 species were survivors. The ostracods assemblages slowly recovered during the Serpentinum Biochron.

Overall, more than $60 \%$ of the benthic species considered at La Almunia-Ricla disappeared during the latest Pliensbachian and the earliest Toarcian. Similar extinction patterns and timing have been observed in several sections of the Iberian Range, like in the Rambla del Salto (Sierra Palomera) section (Comas-Rengifo et al., 1996), confirming a latest Tenuicostatum-earliest Serpentinum age for the mass extinction boundary.

Fig. 7. Stratigraphic column of the La Almunia-Ricla section. Sequence stratigraphy has been based on lithological, palaeontological and palaeoecological observations and supported by gamma-ray field measurements. For the ammonite-based biostratigraphy, only the distribution of the most significant species useful for the definition of zones and subzones has been included. Stable isotope curves $\delta^{18} \mathrm{O}_{\text {bel }}$ and $\delta^{13} \mathrm{C}_{\mathrm{bel}}$ of the uppermost Pliensbachian and Toarcian were obtained from belemnite calcite. Zones abbreviations: PSE-Pseudoradiosa. Subzones abbreviations: ELElegantulum. VI-Vitiosa. BI-Bingmanni. TH-Thouarsense. FS-Fascigerum. FL-Fallaciosum. GR-Gruneri. PS-Pseudoradiosa. AA-Aalensis. 


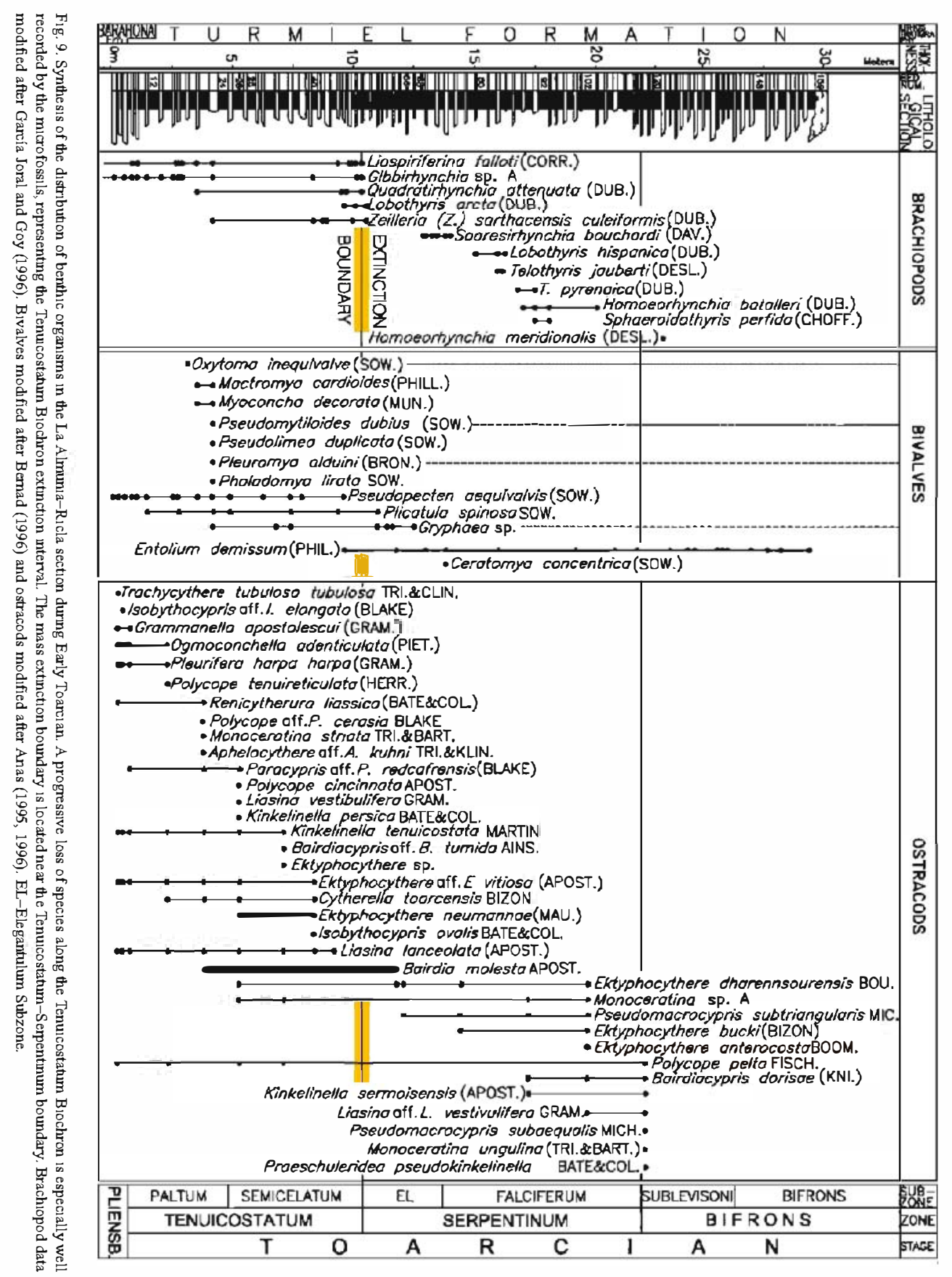




\section{Comparison between the Asturian and the Iberian platform system stable isotope records}

\subsection{Carbon isotope records}

Comparison of the $\delta^{13} \mathrm{C}$ curves obtained in Asturias (Rodiles-Santa Mera section) and in the Iberian platform system (La Almunia-Ricla section) is displayed in Fig. 10. Late Pliensbachian and earliest Toarcian (Paltum Biochron) $\delta{ }^{13} C_{\text {bel }}$ values are relatively low, averaging around 0.8 to $1 \%$ in both sections. However, a significant positive excursion (values surpassing 3\%o) develops in both areas from the Paltum Biochron up to the Falciferum Biochron, even though not synchronously. The main positive excursion and the black shale facies have been recognized in the Rodiles-Santa Mera section, but the negative $\delta{ }^{13} \mathrm{C}$ excursion is not detected by the belemnite calcite. However, a $-1.5 \%$ o $\delta^{13} \mathrm{C}$ shift has been found in bulk carbonate samples, the boundaries of the negative excursion being fully coincident with the boundaries of

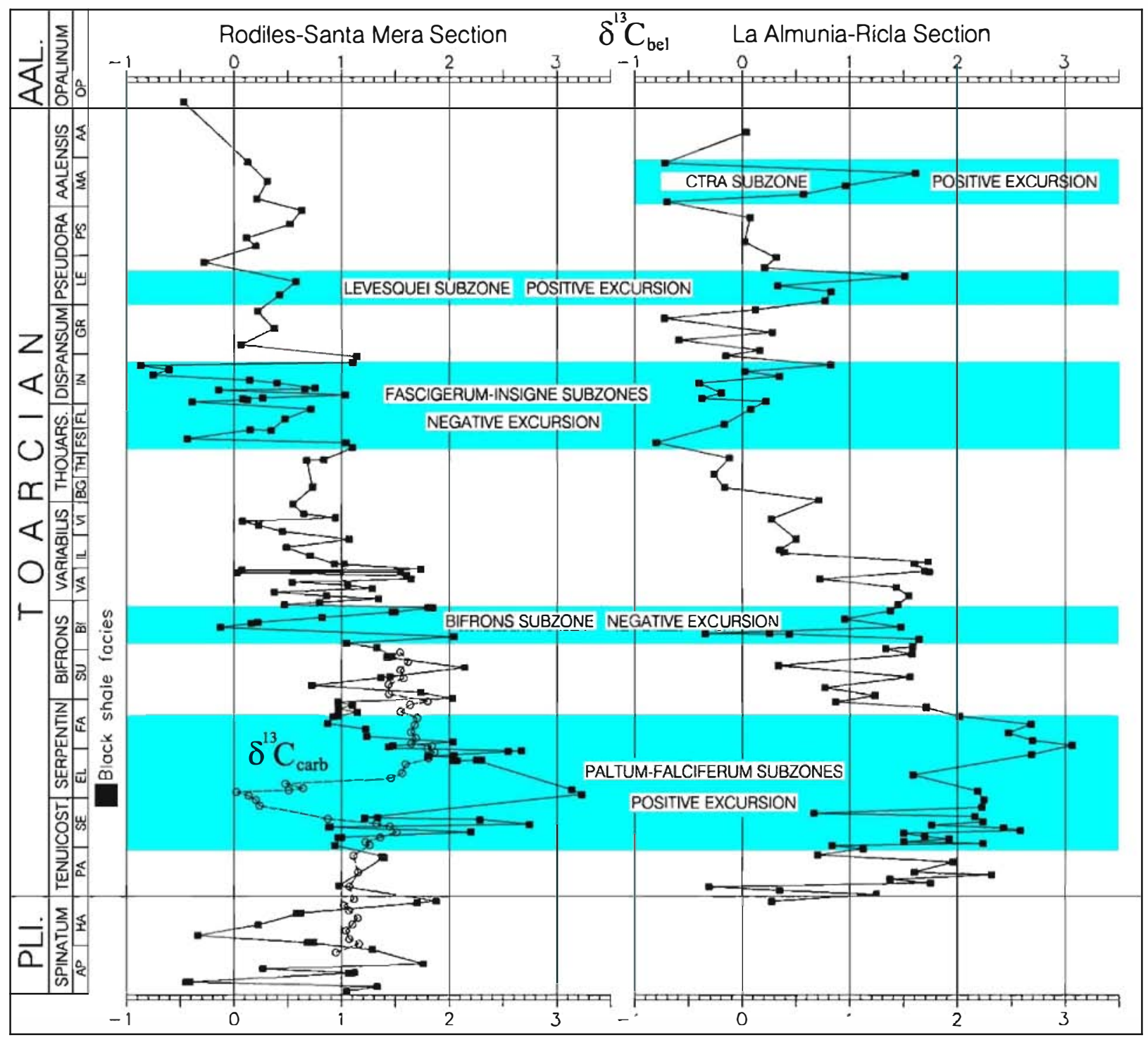

Fig. 10. Correlation chart of the uppermost Pliensbachian-Toarcian $\delta^{13} \mathrm{C}_{\mathrm{bel}}$ curves obtained in the Rodiles-Santa Mera and in the La Almunia-Ricla sections. Notice the positive excursion starting at the middle Tenuicostatum Biochron (PaltumSubzone) and extending up to the Falcif erum Biochron of the Serpentinum Zone. From this positive shift, $\delta^{13} \mathrm{C}_{\mathrm{bel}}$ values tend to decrease, reaching negative values at the latest Bifrons Biochron and specially at the middle Thouarsense Biochron and at the middle Dispansum Biochron. The curve tends to recover more positive values, with peaks in the Levesquei and in the Mactra biochrons, which are better marked in the La Almunia-Ricla section. The $\delta^{13} \mathrm{C}_{\text {carb }}$ curve of the Rodiles-Santa Mera section records a well defined negative excursion, coinciding with the presence of black shale facies, around the Tenuicostatum-Serpetinum zonal boundary. Zones/biochrons abbreviations: TENUICOST.-Tenuicostatum. SERPENTIN.-Serpentinum. THOUARS.-Thouarsense. PSEUDORA.Pseudoradiosa. For subzones abbreviations see Fig. 4. 
the black shale interval (Figs. 3 and 10) and containing the Tenuicostatum-Serpentinum zonal boundary. Above this excursion, the $\delta{ }^{13} \mathrm{C}_{\text {carb }}$ values increase, reflecting a positive $\delta^{13} \mathrm{C}$ excursion, which is more evident in the $\delta^{13} \mathrm{C}_{\text {bel }}$ record, although a negative peak has been found in the La Almunia-Ricla section.

During the Middle and Late Toarcian, the $\delta^{13} \mathrm{C}_{\text {bel }}$ curves show lower values, but the presence of several shifts coincident in both sections is noteworthy. After recovering average values of around $1.1 \%$, lower values representing a negative shift in the $\delta^{13} \mathrm{C}_{\mathrm{bel}}$ are reached at the late Bifrons Biochron. Higher in the section, negative values of up to $-0.86 \%$, hereby called Fascigerum-Insigne subzones negative excursion, have also been recorded (Fig. 10). This could represent a significant anomaly in terms of rapid and ephemeral climate change.

\subsection{Oxygen isotope records}

Correlation of the $\delta^{18} \mathrm{O}_{\text {bel }}$ curves obtained in the Asturias area and in the Iberian Range shows strong similarities (Fig. 11). During Late Pliensbachian, $\delta^{18} \mathrm{O}_{\text {bel }}$ average values are relatively high (about $0 \%$ ). However, at the Tenuicostatum Biochron $\delta^{18} \mathrm{O}_{\text {bel }}$ content progressively decreases, reaching minimal values at the Serpentinum Biochron. An important negative excursion

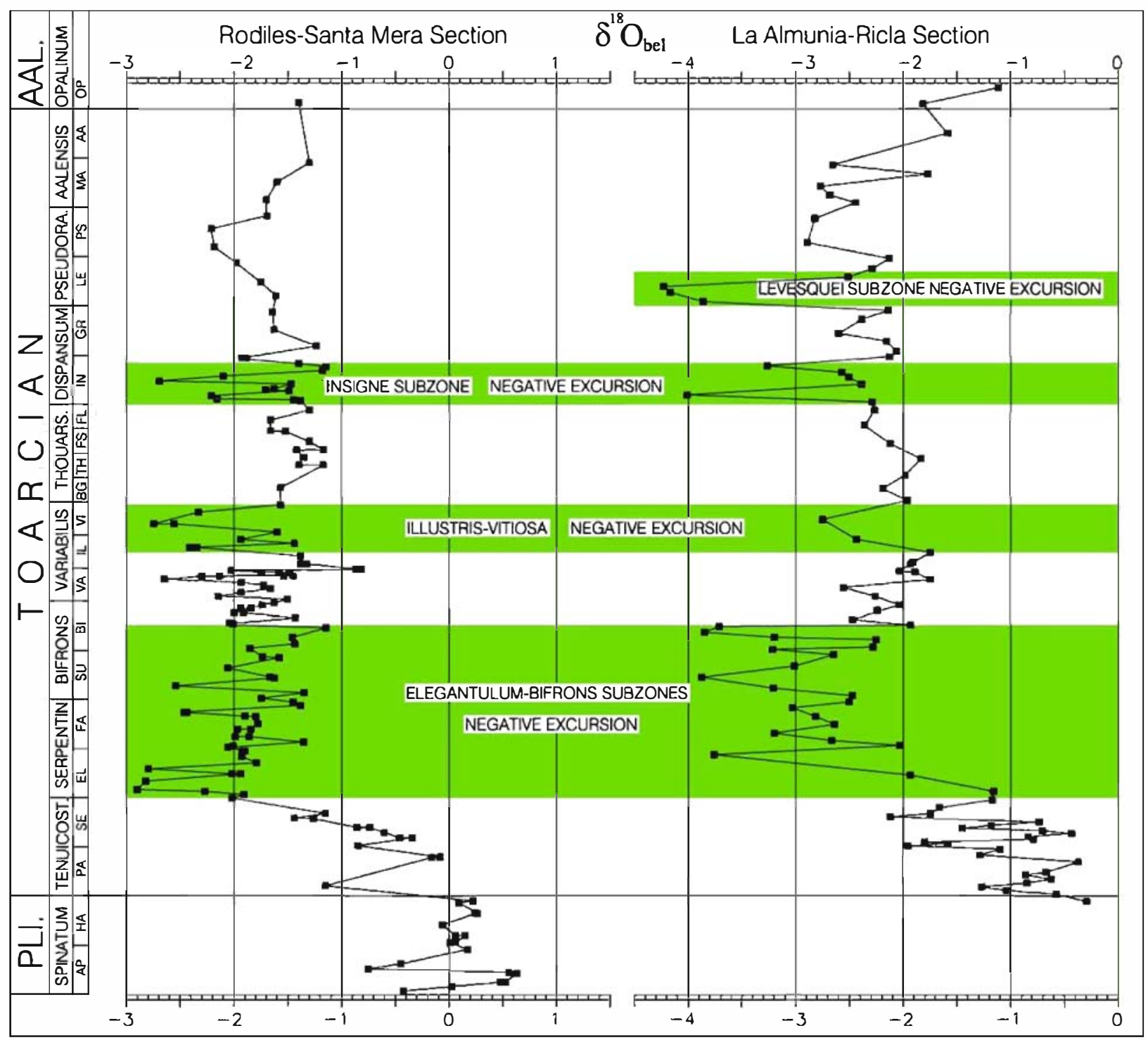

Fig. 11. Correlation chart of the uppermost Pliensbachian-Toarcian $\delta^{18} \mathrm{O}_{\text {bel }}$ curves obtained in the Rodiles-Santa Mera and in the La Almunia-Ricla sections. A main negative excursion starts at the Tenuicostatum Biochron, which rapidly develops during the Serpentinum Biochron, up to the late Bifrons Biochron. Two more negative excursions have been recorded at the Illustris and Vitiosa biochrons and at the Insigne Biochron. The youngest recorded negative excursion was developed at the Levesquei Biochron, but it was only found in the La Almunia-Ricla section. For zones abbreviations see Fig. 10 and for subzones abbreviations see Fig. 4. 
develops from the Elegantulum Biochron up to the latest Bifrons Biochron, on which the $\delta^{18} \mathrm{O}_{\text {bel }}$ values dramatically decrease, reaching peak values of up to $-3.8 \%$ in the La Almunia-Ricla section.

After a short increase in the $\delta^{18} \mathrm{O}_{\text {bel }}$ values, three minor additional negative shifts have been recorded in MiddleUpper Toarcian deposits. The lower one, having values up to $-2.7 \%$, was recognized in deposits of the upper Variabilis Zone (part of the Illustris and Vitiosa subzones). The middle excursion, which occurs at the Insigne Biochron, is integrated into a negative $\delta^{13} \mathrm{C}_{\mathrm{bel}}$ excursion also recorded in both sections. The two lower anomalies are better documented in the Rodiles-Santa Mera section, whilst the uppermost negative shift, recorded in the Levesquei Subzone (Pseudoradiosa Zone), has only been detected in the Iberian Range, where several values below $-4 \%$ o were assayed (Fig. 11).

The $\delta^{18} \mathrm{O}$ values obtained from bulk carbonates were unreasonably low, indicating that the original signal has been severely affected during burial diagenesis. This phenomenon was forecasted on the bases of the luminescent character of the carbonate matrix, tested during the cathodoluminescence studies (Fig. 2).

\section{Palaeotemperature variations}

For palaeotemperature calculation, it has been assumed that 1) the sampled non-luminescent biogenic calcite of the belemnite rostra collected in the Toarcian deposits of the two studied sections precipitated in equilibrium with the seawater, 2) biogenic calcite retains the primary isotopic composition of the seawater, 3) sampling bias, vital effects, skeletal growth and belemnite migration are not the main factors responsible for the obtained variations in the $\delta^{18} \mathrm{O}$ values, and consequently that the resultant curve essentially reflects changes in environmental parameters (Sælen et al., 1996; McArthur et al., 2007).

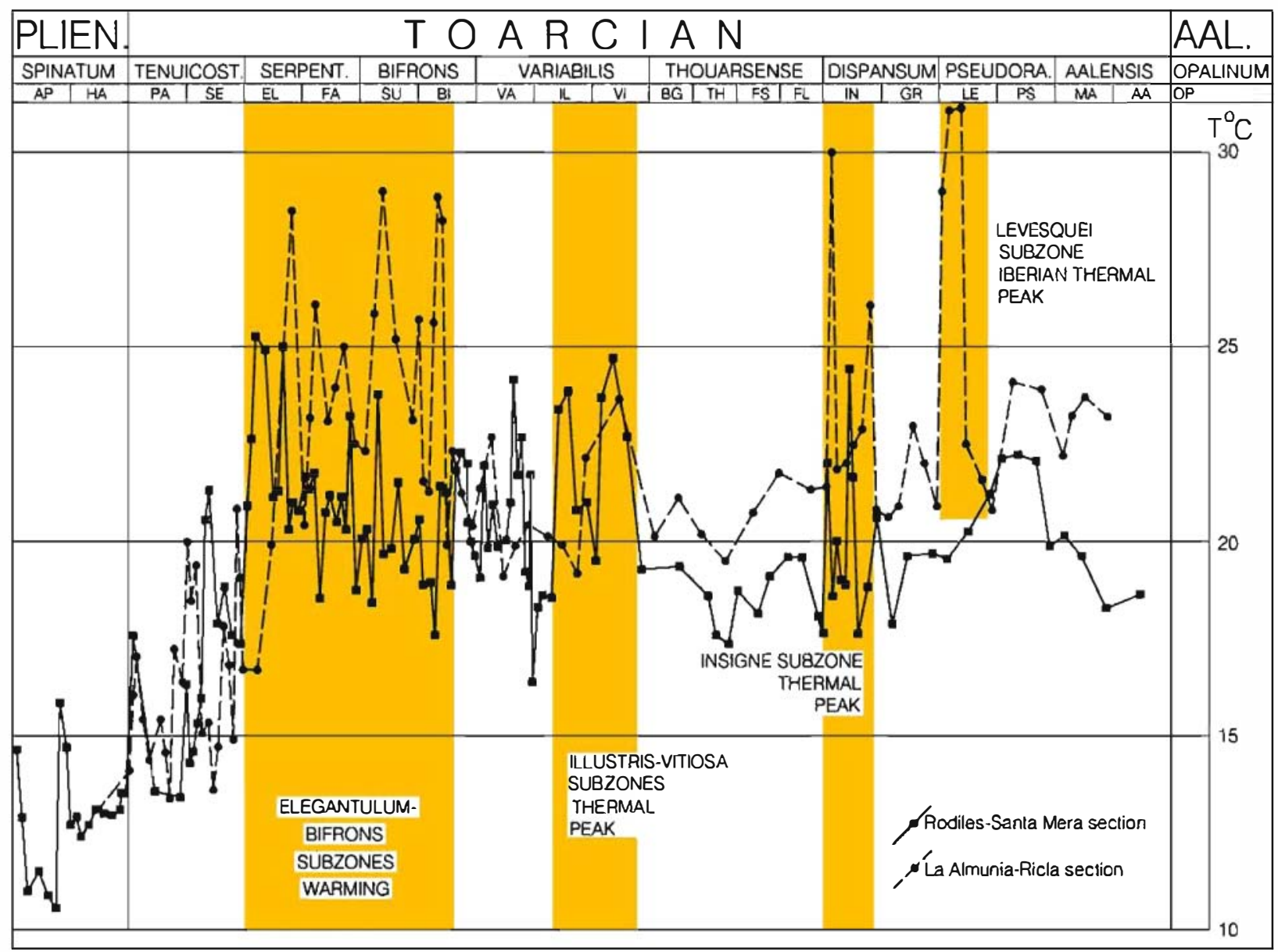

Fig. 12. Palaeotemperature curves obtained from the $\delta^{18} \mathrm{O}_{\text {bel }}$ values recorded in the Rodiles-Santa Mera and in the La Almunia-Ricla sections. From a cool interval at the latest Pliensbachian, a main warming interval was reached from the Tenuicostatum-Serpentinum boundary up to the latest Bifrons Biochron. A new short-term warming interval, the Illustris-Vitiosa subzones thermal peak, occurs in the middle-late Variabilis Biochron. At the Insigne Biochron, a new thermal peak, recorded in both areas is observed, and an increment of the temperature has been localized in the La Almunia-Ricla section at the early Pseudoradiosa Biochron. For zones abbreviations see Fig. 10 and for subzones abbreviations see Fig. 4. 
The Toarcian seawater temperatures recorded in the belemnite rostra have been calculated using the Anderson and Arthur (1983) equation:

$$
\mathrm{T}\left({ }^{\circ} \mathrm{C}\right)=16.0-4.14\left(\delta_{\mathrm{c}}-\delta_{\mathrm{w}}\right)+0.13\left(\delta_{\mathrm{c}}-\delta_{\mathrm{w}}\right)^{2}
$$

where $\delta_{\mathrm{c}}=\delta^{18} \mathrm{O}$ PDB composition of the sample, and $\delta_{\mathrm{w}}=\delta^{18} \mathrm{O}$ SMOW composition of ambient seawater. Normal values of $\mathrm{S}=34.3 \%$ o for the marine salinity (Wright, $1987)$ and $\delta_{\mathrm{w}}$ values of $-1 \%$ for a non-glacial ocean water were assumed.

The temperature variations during the Toarcian in the two studied sections are shown in Fig. 12. At the uppermost Pliensbachian Spinatum Zone, the palaeotemperatures tested in the Rodiles-Santa Mera section shows relatively low values, averaging $11.6^{\circ} \mathrm{C}$. Similar temperatures were obtained by Rosales et al. (2004) in the Basque-Cantabrian basin in Northern Spain, indicating a relatively cool interval for the uppermost Pliensbachian, which has also been recorded in Germany by Bailey et al. (2003).

The beginning of the Toarcian coincides with the transition to a warmer interval, which extends up to the latest Tenuicostatum Biochron. The average measured palaeotemperature was $15.6^{\circ} \mathrm{C}$ in the Rodiles-Santa Mera section, and $16.3{ }^{\circ} \mathrm{C}$ in the La Almunia-Ricla section. That represents a first interval of increasing temperature in the platforms in the order of $4-5^{\circ} \mathrm{C}$.

The main warming interval was developed from the Tenuicostatum-Serpentinum transition, up to the late Bifrons Biochron. Average palaeotemperatures of $21^{\circ} \mathrm{C}$ in the Rodiles-Santa Mera section and $24.1^{\circ} \mathrm{C}$ in the $\mathrm{La}$ Almunia-Ricla section were reached. That represents a $\Delta T$ in the order of $5.7^{\circ} \mathrm{C}$ and about $7.8^{\circ} \mathrm{C}$ respectively. During this warming episode, peak values of up to $29^{\circ} \mathrm{C}$ were occasionally reached in the La Almunia-Ricla section, whilst in the Rodiles-Santa Mera section, palaeotemperatures of $25{ }^{\circ} \mathrm{C}$ were rarely surpassed. The range of seawater temperatures reached is compatible with the temperature values measured in current oceans by the National Oceanic and Atmospheric Agency (NOAA). For a calculated Madrid palaeolatitude of about $35-36^{\circ} \mathrm{N}$ in the Toarcian (Osete et al., 2000), average palaeotemperatures of this warming interval were in the order of $2-5^{\circ} \mathrm{C}$ higher than in the present-day oceans at a similar latitude.

After the main warming interval, a decrease in the seawater temperatures is recorded. Average calculated palaeotemperatures were in the order of $19{ }^{\circ} \mathrm{C}$ in the Rodiles-Santa Mera section and $20.5{ }^{\circ} \mathrm{C}$ in the La Almunia-Ricla section, from the latest Bifrons Biochron up to the middle Variabilis Biochron (Illustris Subzone). However, a new short-term relative warming interval, which is represented by the Illustris-Vitiosa subzones thermal peak, (Fig. 12), where maximum temperatures of up to $24.6{ }^{\circ} \mathrm{C}$ in the Rodiles-Santa Mera section and $23.6{ }^{\circ} \mathrm{C}$ in the La Almunia-Ricla section were reached.

A new small decrease in temperature occurs at the Thouarsense Biochron, before the last short waming interval illustrated in both areas that occurred at the Insigne Biochron. During this interval, temperature peaks of up to $24.5^{\circ} \mathrm{C}$ in the Rodiles-Santa Mera section, and up to $30^{\circ} \mathrm{C}$ in the La Almunia-Ricla section were attained.

Average temperatures during most of the latest Toarcian were in the order of $19^{\circ} \mathrm{C}$ in the Rodiles-Santa Mera section, and about $21-22{ }^{\circ} \mathrm{C}$ in the La Almunia-Ricla section, but anomalously high temperatures, that slightly surpassed values of $31{ }^{\circ} \mathrm{C}$, were reached in the Iberian platform system at the Levesquei Biochron. Palaeotemperature values above $31{ }^{\circ} \mathrm{C}$ are considered by some authors as reasonable in the normal marine salinity scenario, but temperatures exceeding $31{ }^{\circ} \mathrm{C}$ are assumed to signal lowered surface water salinities and should be recalculated according to salinity (Sælen et al., 1996). For the recorded palaeotemperatures of $31{ }^{\circ} \mathrm{C}$, recalculated temperature values for a salinity $\mathrm{S}=33 \%$ would be $28.9^{\circ} \mathrm{C}$, which still supports the marked thermal peak of the Levesquei Subzone.

\section{Discussion}

Ammonite-based high resolution stratigraphy of the Toarcian allows good correlation between the studied sections, mainly in Europe, and testing of some of the models proposed to explain the main geo- and bioevents that occurred during this time interval. The outstanding Early Toarcian mass extinction event and the possible causes of this important faunal turnover are of particular interest.

One of the first critical factors for correlation is the elucidation of the equivalence among the different ammonite-based zonal scales performed in the diverse palaeogeographic and palaeobiogeographic realms. A correlation between the Early Toarcian zonal scales of NW Europe, the Mediterranean, Spain and Portugal, and southern Germany, has been summarized in Fig. 13a. This zonal chart will be used to correlate the timing of the different Early Toarcian phenomena recorded in different parts of the world, assuming that zones and subzones boundaries are relatively synchronous.

\subsection{Timing of the Early Toarcian mass extinction}

Maximum resolution on the timing of the extinction is one of the main factors for the assessment of the possible 
causes that contributed to the Early Toarcian mass extinction. The age of this faunal turnover, which is supposed to be a synchronous event of global extent (Little and Benton, 1995; Walliser, 1996) has been a matter of debate. An end-Pliensbachian age was first attributed by Hallam (1986), Raup and Sepkoski (1988) and Sepkoski (1989, 1996), but most diagrams displaying the distribution of the different organisms show a gradual loss during

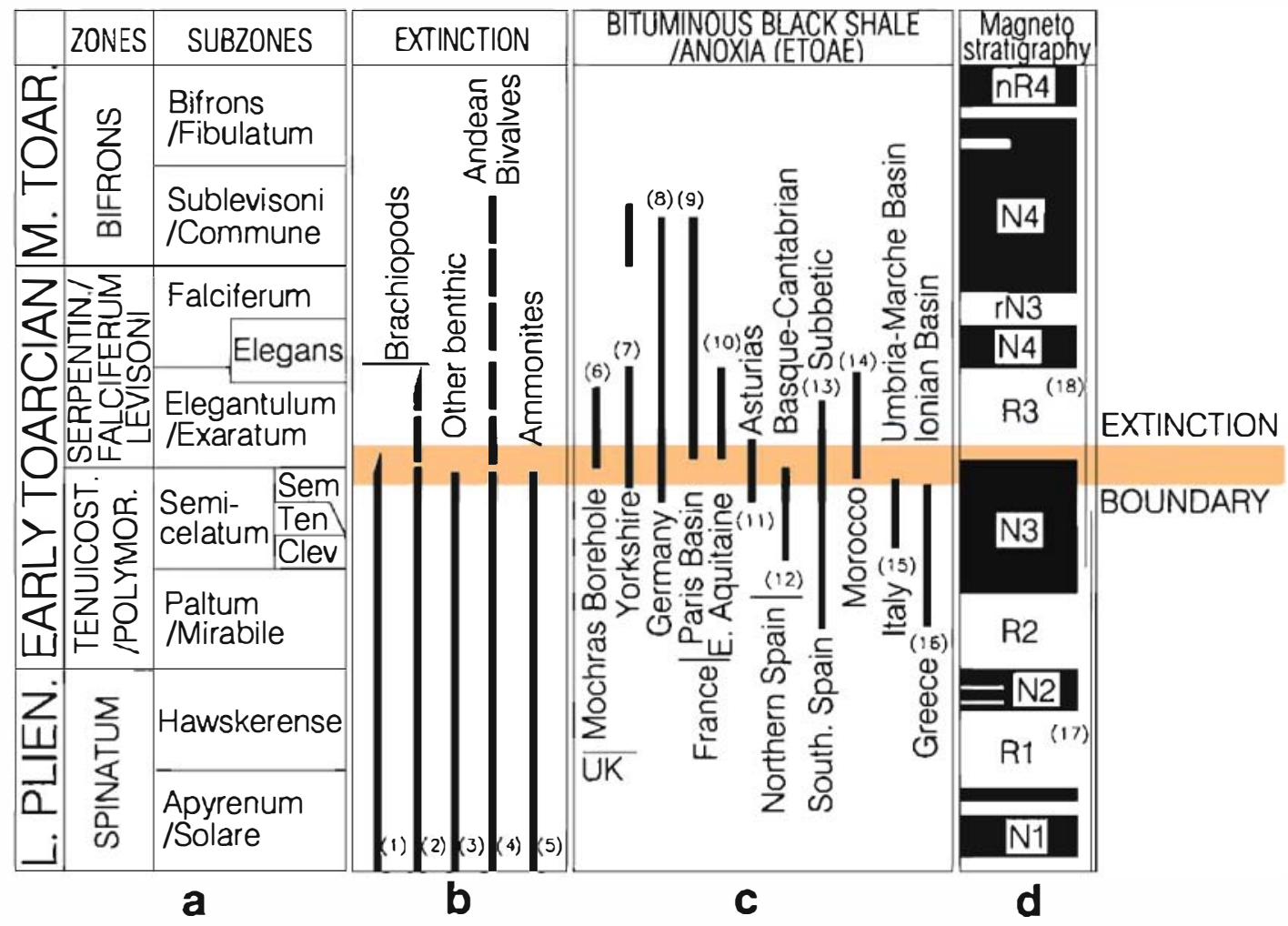

Fig. 13. Correlation chart showing the timing of the major Early Toarcian events. (a) Ammonites zones and subzones (and their equivalent biochrons) after Howarth (1973, 1992), Elmi et al. (1989, 1994, 1997), Hardenbol et al. (1998), Schouten et al. (2000), Röhl et al. (2001), Macchioni (2002), Cecca and Macchioni (2004), Page (2003, 2004), van de Schootbrugge et al. (2005a,b). For the Tenuicostatum Zone, or the equivalent Polymorphum Zone, it has been assumed that the Semicelatum Subzone is equivalent to the Clevelandicum, Tenuicostatum and Semicelatum subzones used in the UK, and that the Semicelaturn Subzone of the German sections includes the Tenuicostatum Subzone of the UK. In the Iberian Range the Semicelatum Subzone has been divided into three horizons: Crosbeyi, Tenuicostatum and Semicelatum, equivalent to the three subzones used in the UK (Goy and Martínez, 1990), indicating a very similar succession. In most of Europe, the Serpentinum (= Falciferum or Levisoni) Zone has been subdivided into Elegantulum (= Exaratum) and Falciferum subzones, except in Germany where an Elegans Subzone is also distinguished. Here we interpret that the German Elegans Subzone corresponds to the uppermost portion of the Elegantulum/Exaratum Subzone and the lower part of the Falcif erum Zone. It is important to notice that there is no conflict or ambiguity in the Tenuicostatum-Serpentinum zonal boundary (or equivalents) in any of the established scales. (b) Comparison between the timing of extinction of the different groups of organisms in several areas. (1) Brachiopods, based on data from Central Spain (García Joral and Goy, 1996; Joral and Goy, 2000; Gahr, 2005); in the UK (Little and Benton, 1995; Harries and Little, 1999). (2) Extinction of the family Koninckinidae in the Tethys and the Laurasian seaway (Almeras and Fauré, 1990; Vörös, 2002). (3) Other benthic organisms except for brachiopods. Includes mainly bivalves, benthic foraminifers and ostracods from Central Spain (Arias et al., 1992; Arias, 1996; Bernad, 1996; Gahr, 2005), UK (Hallam, 1987; Little and Benton, 1995; Hallam, 1996; Harries and Little, 1999; Wignall et al., 2005), Italy (Nocchi and Bartolini, 1994), France and NW Europe (Bassoullet and Baudin, 1994; Barnes et al., 1996; Hylton and Hart, 2000), Portugal (Boomer et al., 1998), Eastern Europe (Ruban and Tyszka, 2005), Morocco (Bassoullet et al., 1991). (4) Bivalves of the South American Andean Basin, (Aberhan and Fürsich, 1997). (5) Ammonites (Little and Benton, 1995; Macchioni, 2002; Macchioni and Cecca, 2002; Cecca and Macchioni, 2004). (c) Timing of deposition of the bituminous organic-rich black shale facies related with the ETOAE. (6) UK, Mochras Borehole (Jenkyns and Clayton, 1997; Jenkyns et al., 2002). (7) UK, Yorkshire Grey Shale Mb and Mulgrave shale Mb (Howarth, 1962; Little and Benton, 1995; Hesselbo and Jenkyns, 1995; Sælen et al., 1996; Harries and Little, 1999; Jenkyns, 2003; Wignall et al., 2005; Kemp et al., 2005; Hesselbo et al., 2007a). (8) SW Germany, Posidonia Shale or Posidonienschiefer (Schouten et al., 2000; Röhl et al., 2001; Schmid-Röhl et al., 2002). (9) France, Schistes Cartons. Paris Basin (Tissot et al., 1971; Hollander et al., 1991). (10) France, Quercy, Eastern Aquitaine (Cubaynes and Fauré, 1981; Riegraf, 1982; Ruget et al., 1988). (11) Northem Spain, Asturias (Goy et al., 1997; this work). (12) Northern Spain, Basque-Cantabrian Basin (Comas-Rengifo et al., 1988; Rosales et al., 2004; Tremolada et al., 2005). (13) Southern Spain, Betic Cordillera (Jiménez et al., 1996). (14) Northem Morocco, South Rift Ridge (Boutakiout and Elmi, 2000). (15) Central Italy, Umbria-Marche Basin (Bartolini et al., 1992; Monaco et al., 1994; Parisi et al., 1996; Bucefalo Palliani et al., 1998; Mattioli et al., 2004; Mailliot et al., 2006). (16) Grece, Ionian Basin (Pettinelli et al., 1997). (d) Magnetostratigraphy (17) Proposed magnetostratigraphic scale for the Late Pliensbachian-Early Toarcian, obtained in Central Spain (Goy et al., 2006). (18) Proposed Magnetic Polarity Time Scale (MPTS) for the Early and Middle Toarcian, obtained in Central Spain (Osete et al., 2007). 
the latest Pliensbachian and the Early Toacian. The extinction boundary was later dated as Early Toarcian in age (Hallam, 1987; Arias et al., 1992; Little and Benton, 1995; Harries and Little, 1999) even in a few cases some authors locate the extinction interval and the extinction boundary at different stratigraphic positions.

In the UK, Harries and Little (1999) reported that the main brachiopod tumover occurs at or slightly later than the Tenuicostatum-Falciferum boundary, and Wignall et al. (2006) mark the extinction boundary at the latest Tenuicostatum Biochron. In the La Almunia-Ricla section, an age around the Tenuicostatum-Serpentinum biochrons boundary has been established (Garcia Joral and Goy, 1996; Figs. 9 and 13b-1), and lately tested in 10 additional sections in the Iberian Range (Joral and Goy, 2000; Gahr, 2005). In contrast, Vörös (2002) locates the extinction of the family Koninckinidae at the Falciferum Zone (Fig. 13b-2). However, Almeras and Fauré (1990) determine the age of the extinction boundary in Portugal stating that this family do not surpass the TenuicostatumSerpentinum boundary.

Referring to other benthic organisms, including bivalves, foraminifers, gastropods and ostracods, the most widely accepted age for the extinction boundary in Europe is again around the Tenuicostatum-Serpentinum boundary (Fig. 13b-3). Nevertheless, in the Andean Basin in South America, Aberhan and Fürsich (1997) reported a drastic decrease in bivalves diversity during the EarlyMiddle Toarcian (Fig. 13b-4). However, the relatively difficult correlations between the Andean Basin and Europe makes this age uncertain. Also Hallam (2006) and Wignall et al. (2006) report that the extinction losses found in Tibet occurred in the later part of the Toarcian. However, the possibility that these biotic crisis correspond with other younger Toarcian turnover events mentioned below, cannot be discarded.

An age around the Tenuicostatum-Serpentinum zonal boundary has also been reported for the peak of maximum extinction of ammonoids, preceded by a first diversity drop recorded in the Pliensbachian-Toarcian boundary (Cecca and Macchioni, 2004; Fig. 13b-5), this being more remarkable at the Mediterranean province than in the Boreal realm. In spite of it cannot be considered as an extinction event, Cobianchi and Picotti (2001) and Erba (2004) reported a general crisis decline of the phytoplankton schizosphaerellids in Northern Italy around the Pliensbachian-Toarcian boundary, which reaches a maximum around the TenuicostatumSerpentinum zonal boundary in Northern Spain (Tremolada et al., 2005).

Based on the available data, a late Semicelatum-early Elegantulum biochrons as the age of the extinction boundary seems reasonable, even some authors point out that the extinction boundary corresponds to the late Semicelatum Biochron (Wignall et al., 2005). Mass extinction is supposed to be a synchronous and global event, but the possibility that it could occur slightly earlier or later in some areas, due to local conditions, cannot be discarded. Instead of a line, we have represented the extinction boundary as a short time interval in Figs. 8, 13, 15 and 16.

\subsection{Timing of deposition of the organic-rich facies linked to the Early Toarcian Oceanic Anoxic Event (ETOAE)}

The ETOAE is regarded as a short period of time during which much of the global ocean became strongly anoxic, resulting in the widespread deposition of organicrich sediments (e.g. Jenkyns and Clayton, 1986; Jenkyns, 1988; McArthur et al., 2000). The ETOAE produced anomalously high rates of carbon burial, which caused a part of the marine environments to become poorly oxygenated (Jenkyns, 1999; Jenkyns et al., 2002). In addition, the ETOAE has been lately associated with the presence of a pronounced negative $\delta^{13} \mathrm{C}$ excursion which is for some authors of global extent (Hesselbo et al., 2007a).

Lower Toarcian organic-rich facies have been reported in many areas of the world, as summarized by Jenkyns (1988) and Jenkyns et al. (2002), and have been mapped and studied in many areas of Europe (Fig. 14). Apparent synchronism between the anoxic to suboxic facies and the mass extinction boundary was the main reason to assume that the environments generated at the ETOAE were the main causal mechanisms to explain the extinction recorded during the Early Toarcian (e.g. Jenkyns, 1988; Nikitenko and Shurygin, 1992; Bassoullet and Baudin, 1994; Harries and Little, 1999; Pálfy and Smith, 2000; Jenkyns et al., 2002; Vörös, 2002; Hart et al., 2003; Tremolada et al., 2005; Wignall et al., 2005). However, comparison of timing of black shale facies deposition in the different areas of Europe and Northern Africa, on the basis of high-resolution ammonite biostratigraphy, evidences discrepancies concerning the synchronism of the deposition of the organic-rich facies linked to the ETOAE.

In the sections of the UK containing black shale facies, deposition of the organic-rich sediments started in the latest Semicelatum Biochron (Hesselbo and Jenkyns, 1995; Wignall et al., 2005), or at the TenuicostatumFalciferum zonal boundary (Harries and Little, 1999) and was mainly developed at the Exaratum Biochron in most areas (Fig. 13c-6, 7). In Germany, the onset of the black shale facies Posidonia Shale is upper Semicelatum and the top of the organic-rich facies is upper Bifrons Zone (Fig. 13c-8). In France, the Schistes Cartons of the Paris 
Basin were deposited at the Falciferum and part of the Bifrons biochrons (Fig. 13c-9) and in Eastern Aquitaine at the lower Serpentinum Biochron (Fig. 13c-10).

In Northern Spain, ammonites collected in the black shale facies of the Rodiles-Santa Mera section indicate that the Tenuicostatum-Serpentinum boundary is recorded within the thin laminated organic-rich facies interval (Figs. 6 and 13c-11), but in the Basque-Cantabrian Basin, also in Northern Spain, the black shales are older, as they were deposited at the Semicelatum Biochron (Fig. 13c-12) and the earliest Serpentinum Biochron. In the Alpine domain, black shale facies seems to be patchy (Fig. 14) and the timing of anoxic/dysoxic facies is quite heterogeneous. In the Subbetic area of Southern Spain, the black shale facies are only locally present (Fig. 14), and its age looks to span from the Polymorphum to the early Serpentinum biochrons (Fig. 13c-13). The beginning of deposition of the black shales again predates the age found in NW Europe. Taking into account that the Polymorphum-Serpentinum boundary is older in the Subbetic than the NW Europe Tenuicostatum-Serpentinum zonal boundary (Elmi et al., 1989), it is possible that the onset of the black shale facies in the Subbetic is older than the Tenuicostatum Biochron of the NW Europe scale. In the
Northern Morocco Rift domain, black shale facies seems to be scarce and patchy (Fig. 14) and they have been locally dated as the interval from latest Polymorphum to the latest Levisoni biochrons (Figs. 13c and 14). In the Central Italy Umbria-Marche Basin, most data indicate that the age of the black shales is Tenuicostatum Biochron, before the Serpentinum Biochron (Fig. 13c-15) and in the Ionian Basin, in Greece, the black shales seem to be constrained to the Tenuicostaum (=Polymorphum) biochron (Fig. 13c-16).

It can be inferred from the correlation panel that the onset of deposition of black shales related to the ETOAE is not a synchronous event at the ammonite zone or subzone scale and, in general, a rough polarity trend from southeast to northwest can be observed. In the Mediterranean area, deposition of the black shale facies took place mostly at the Tenuicostatum Biochron, and in the NW European platform it mostly started at the earliest Serpentinum Biochron and in some cases at the latest Tenuicostatum Biochron. The end of deposition of organic-rich facies is even more diachronous.

The Lower Toarcian black shales were not deposited in nearly all marine environments, as suggested by Tremolada et al. (2005). In many areas of the Toarcian

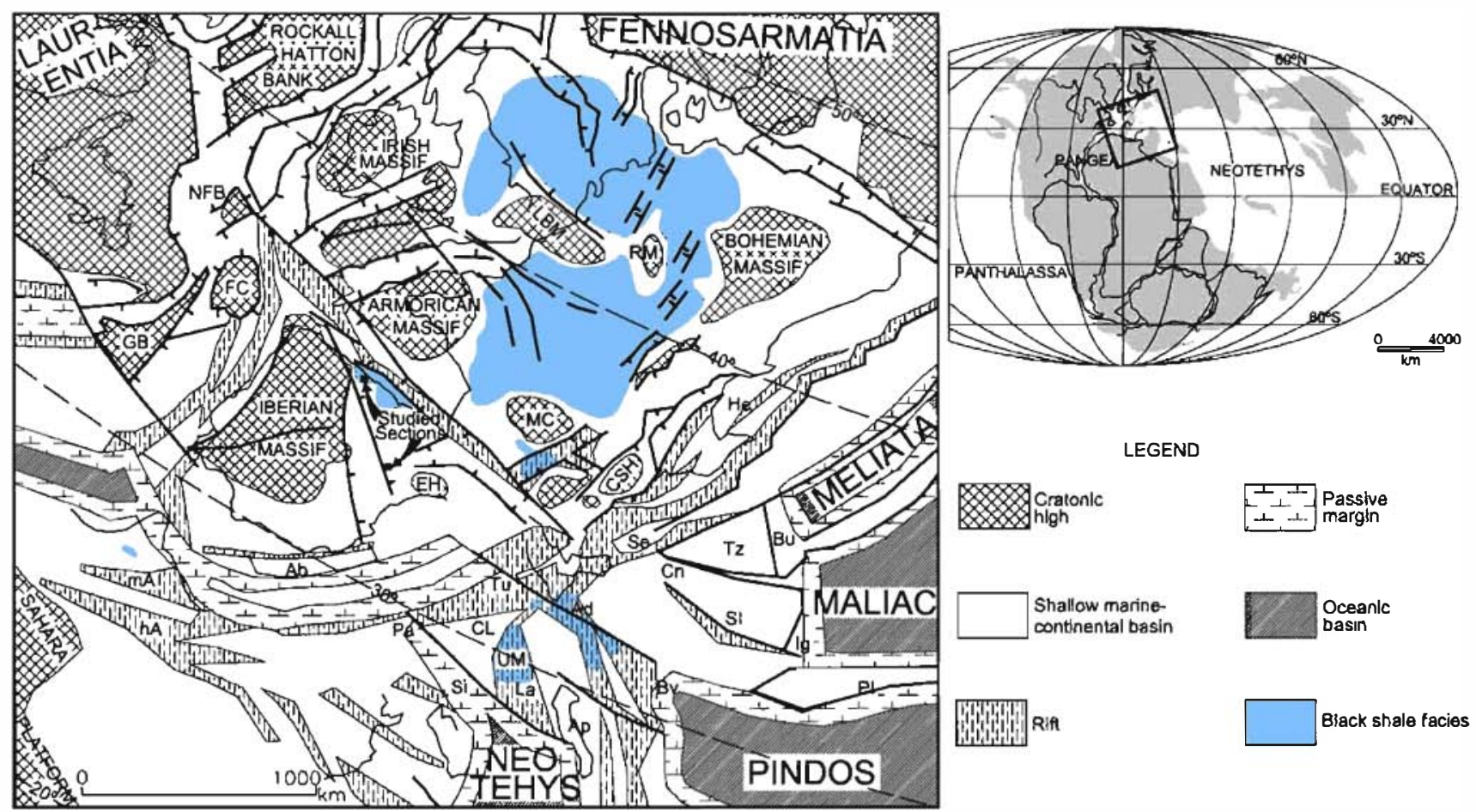

Fig. 14. Toarcian palaeogeography of Westem Tethys and the Proto-Atlantic Ocean (modified after Ziegler, 1990; Vera, 2001; Stampfli and Borel, 2004; Golonka, 2006) showing the location of the studied sections. Black shale facies distribution based on data from Jenkyns (1988), Bassoullet et al. (1991), Parisi et al. (1996), Boutakiout and Elmi (2000), Bucefalo Palliani et al. (1998), Vera (2001), Goričan et al. (2003), van de Schootbrugge et al. (2005a,b). The position and extension of the organic-rich shales in the Alpine-Mediterranean region is highly uncertain due to their sporadic occurrence. Abbreviations: AbAlboran. Ad-Adria s. str. Ap-Apulia s. str. Bu-Bucovinian. CL-Campania Lucania. Cn-Camic-julian. GB-Grand Bank. hA-High Atlas. He-Helvetic rim basin. Ig-Igal trough. La-Lagonegro. LBM-London-Braband Massif. mA-Middle Atlas. MC-MassifCentral High. NFB-East Newfoundland Basin. PaPanormides. Pl-Pelagonian. Se-Sesia (westem Austroalpine). Si-Sicanian. Sl-Slavonia. Tu-Tuscan. Tz-Tizia. UM-Umbria-Marche. 


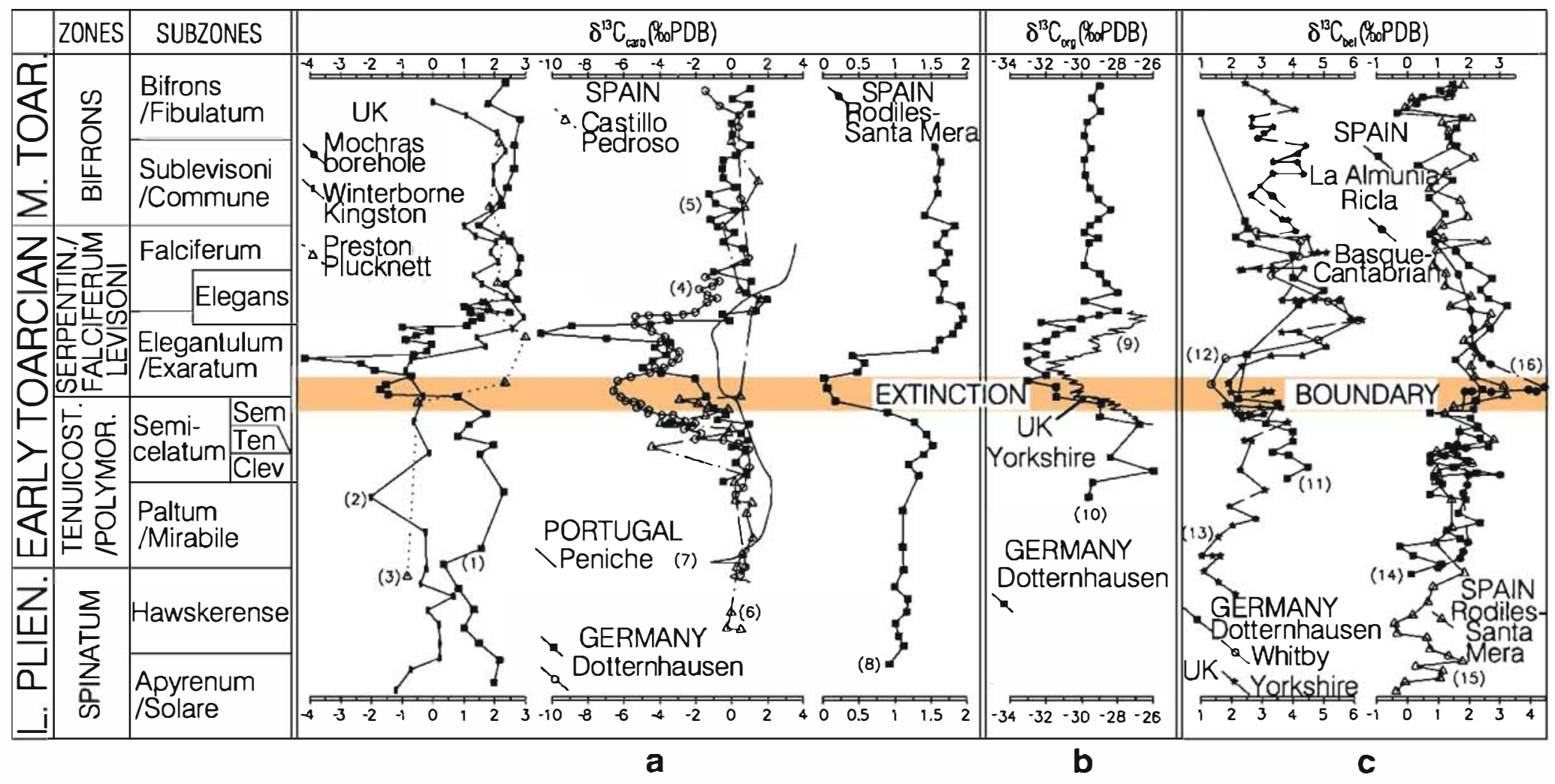


platform system, such as several areas of Spain (Iberian and Catalan Coastal ranges, Pyrenees, Prebetic, part of Subbetic, Fig. 1), in Portugal and in some zones of the Alpine-Mediterranean region, conditions were not favourable for the development of organic-rich deposits and, consequently, black shale facies are absent or extremely thin.

To reconcile the diachronous character of black shale deposition between Mediterranean/Submediterranean and the NW European provinces, maintaining anoxia as the main cause of mass extinction, Wignall et al. (2005) propose a scenario on which anoxia finished in the Tethyan area (including the Basque-Cantabrian Basin) at the mid Semicelatum Biochron, whilst it started in the Boreal Realm at the late Semicelatum Biochron, experiencing a coincidence in both areas at the mid Semicelatum Biochron of the UK scale, which conditioned the extinction of the benthos. It should be taken into account that if anoxia is the main cause of mass extinction, the extinction would start with the onset of anoxia in each part of the basin (Fig. 13c) and extinction would be as diachronous as the black shale facies and not of global extent. No overlap in the temporal distribution of black shales in all Europe is proven and in any case it could not necessarily coincide with the extinction boundary. As a consequence, no strong cause-effect link between Early Toarcian mass extinction and marine anoxia is supported by available data.
Additionally, in the Wignall et al. (2005) sketch, a palaeogeographical high would separate the Boreal basins from the Tethys ocean. None of the published palaeogeographical maps (e.g. Fig. 14) shows a continuous high drastically separating both domains. The Basque-Cantabrian Basin should not be included in the Tethyan side, as the ammonite assemblages indicate that Boreal faunas are common, and notably more abundant than in the Central Spanish sections (Braga et al., 1988), demonstrating a good communication with the Boreal and the Mediterranean provinces.

Jenkyns et al. (2002) defended that levels with maximum TOC can be a time-constant horizon, and that the recorded different ages for the ETOAE can be in agreement if correlation between the basins is made with the FODs of the ammonites genus Hildaites. This possibility is analyzed by Wignall et al. (2005), pointing out that a disadvantage for this assumption is that the first and last appearances of all other ammonites becomes diachronous, concluding that the ETOAE is not synchronic. However, based on quantitative biochronology on calcareous nannofossils, Mailliot et al (2006) considered that the ETOAE is a synchronous or slightly diachronous event within the western Tethys. Finally, Hesselbo et al. (2007a) accept that deposition of marine organic-rich shales is "near-synchronous", and that diachroneity is caused by the use of different ammonite taxa to identify boundaries of the biozones at different locations.

Fig. 15. Correlation and timing of the Early Toarcian $\delta^{13} \mathrm{C}$ negative excursion. (a) $\delta^{13} \mathrm{C}$ negative excursion recorded in bulk carbonates (1) UK, Mochras Borehole (Jenkyns and Clayton, 1997; Jenkyns et al., 2002). (2) UK, Winterborne Kingston Borehole (Jenkyns and Clayten, 1997; Jenkyns et al., 2002). (3) UK, Preston Plucknett (Jenkyns and Clayton, 1997). (4) Germany, Dottemhausen (Schouten et al., 2000). (5) Germany, Dottemhausen (Röhl et al., 2001; Schmid-Röhl et al., 2002; van de Schootbrugge et al., 2005a,b). (6) Northem Spain, Basque-Cantabrian Basin (Tremolada et al., 2005). (7) Portugal, Lusitanian Basin (Hesselbo et al., 2007a). (8) Northern Spain, Asturias, (this work). Some of the $\delta^{13} \mathrm{C}$ values obtained in a number of bulk carbonate samples suggest that they could be influenced by diagenetic processes. (b) Correlation and timing of the $\delta^{13} \mathrm{C}$ negative excursion in marine organic matter. (9) UK, Yorkshire, (Jenkyns et al., 2001; Kemp et al., 2005; Hesselbo et al., 2007a). (10) Germany, Dotternhausen (Röhl et al., 2001). (c) Correlation and timing of the $\delta^{13} \mathrm{C}$ curves obtained from belemnite calcite. (11) Germany, Dottcmhausen (van de Schootbrugge et al., 2005a,b). (12) UK, Whitby (Represented values are average values calculated for each stratigraphic interval covered by Sælen et al., 1996). (13) UK, Yorkshire (McArthur et al., 2000). (14) Central Spain, La Almunia-Ricla section (this work). (15) Northern Spain, Rodiles-Santa Mera section (this work), (16) Basque-Cantabrian Basin (Rosales et al., 2001a). Notice that in some sections of the UK (Mochras Borehole, a-1) and in Yorkshire (b-9), the negative shift starts with deposition of black shales in these areas, but a sudden $\delta^{13} \mathrm{C}$ shift towards more negative values coincides with the extinction boundary interval and is mainly developed in the Exaratum Biochron. The negative $\delta^{13} \mathrm{C}$ excursion is not very pronounced in other sections of the UK like the Winterborne Kingston Borehole, where black shale facies containing up to $4.2 \mathrm{wt} \%$ TOC are present, and in the Preston Plucknett section, where black shale facies are absent (a-2, 3). Poor development of the negative excursion in these two UK sections can be due to low sample resolution. Data from Dotternhausen, in Southem Germany, are slightly conflictive with respect to the timing of the negative $\delta^{13} \mathrm{C}$ shift. Schouten et al. (2000) locate the main negative excursion starting in the Semicelatum Biochron, coinciding with the onset of bituminous shale deposition, and extending up to the Elegantulum Biochron (a-4). That would mark the beginning of the $\delta^{13} \mathrm{C}$ negative anomaly coincident with the onset of the black shale facies, and the maximum development of the negative $\delta^{13} \mathrm{C}$ excursion within the extinction boundary. This has also been recorded in the Rodiles-Santa Mera section (a-8). However, in the same area of Germany, the negative $\delta^{13} \mathrm{C}$ anomalies presented by Röhl et al. (2001) and Schmid-Röhl et al. (2002) does not fully coincides with the Schouten et al. (2000) curve. The onset of the Röhl et al. (2001) and Schmid-Röhl et al. (2002) $\delta^{13}$ Cnegative anomaly appears to coincide with deposition of the organicrich shales, and its maximum development is reached during the Exaratum Subzone (a-5; b-10). In the data presented by Tremelada et al. (2005) from the Basque-CantabrianBasin, in Northem Spain, the $\delta^{13} \mathrm{C}_{\text {carb }}$ curve records the onset of the negative excursion in the late Tenuicostatum Biochron, coinciding with the beginning of the black shale facies, but another peak, coincident with the extinction boundary, is also recorded (a-6). In the Lusitanian Basin of Portugal (a-7), where no or very thin organic-rich facies are reported, the negative $\delta^{13} \mathrm{C}$ excursion starts in the Polymorphum-Levisoni zonal boundary, coinciding with the extinction boundary, and develops at the Levisoni Biochron (Duarte, 1998; Duarte et al., 2004; Hesselbo et al., 2007a). 
Even if the ETOAE is synchronous and it coincided with the Early Toarcian extinction boundary, causal effect is unclear, as extinction is also recorded in areas where no black shale facies are present, like in the La Almunia-Ricla section and many other sections of Europe. In addition, in other parts like in the BasqueCantabrian Basin anoxic conditions finished nearly coincident with the mass extinction boundary. Even though many of the mass extinction seems to be related to marine anoxia (Wignall, 2001), not in all the cases they are directly linked. Anoxia could be an important contributor to local biotic crisis, as commonly occurs in the oxygen-depleted sea bottoms, but they are not necessarily synchronous and global.

In summary, the available data from Europe and Northern Africa do not support a synchronism for the deposition of the organic-rich black shale facies related with the ETOAE and, consequently, a direct causeeffect relationship with the Early Toarcian mass extinction cannot be established.

Synchrony between these phenomena as well as the warming and extinction events can be also tested by an independent method in future work. A new magnetostratigraphic scale for the Late Pliensbachian-Middle Toarcian, based on Spanish sections from the Iberian Range, has been proposed by Goy et al. (2006) and Osete et al. (2007). The Toarcian Magnetic Polarity Time Scale (MPTS) shows the presence of a magnetic polarity change at the earliest Serpentinum Biochron (Fig. 13d), between normal polarity interval N3 and reverse polarity interval $\mathrm{R} 3$. This change, supposed to be global and synchronous, is located relatively close to the extinction boundary, and it could represent an additional high-resolution correlation tool in the future.

\subsection{The Early Toarcian negative $\delta^{13} \mathrm{C}$ excursion}

The presence of a remarkable negative $\delta^{13} \mathrm{C}$ excursion recorded in the Lower Toarcian bulk carbonates, marine organic matter and wood, followed by a positive or bracketed between two positive excursions, has been reported in many sections of NW Europe and Tethys (Fig. 15a-b).

Correlation of the available data indicates that the onset of the Early Toarcian negative $\delta^{13} \mathrm{C}$ excursion appears to be diachronous with respect to the ammonites zonal scale and that in some localities it is related to the onset of the deposition of organic-rich facies. Available data do not support that all the Lower Toarcian carbon isotope excursions are more synchronous and have a better stratigraphic resolution than the zonal scales based on ammonites. Hence more research work is needed to use them as high-resolution global stratigraphic markers. However, in most of the studied curves, a rapid decrease in the $\delta^{13} \mathrm{C}$ values is observed around the Tenuicostatum-Serpentinum zonal boundary.

\subsection{The origin of the $\delta^{13} \mathrm{C}$ negative excursions}

The origin of the Early Toarcian $\delta^{13} \mathrm{C}$ negative excursions is strongly controversial, as three different hypotheses are defended. One group of papers states that the Early Toarcian $\delta^{13} \mathrm{C}$ negative excursion is a local signature of the euxinic basin, caused by recycling of isotopically light dissolved inorganic carbon into the photic zone from the lower water column of an intermittently salinity stratified water mass (Küspert, 1982; Sælen et al., 1996, 1998, 2000; Schouten et al., 2000; Röhl et al., 2001; Schmid-Röhl et al., 2002; van de Schootbrugge et al., 2005a; Wignall et al., 2006). However, the so-called Küsper model has been questioned by van Breuguel et al. (2006) as the $\delta^{13} \mathrm{C}$ of isorenieratane indicated that the respired $\mathrm{CO}_{2}$ contribution was not likely to be the main cause of the high amplitude negative excursion recorded in the Toarcian organic carbon from the Paris Basin. In addition, the occurrence of the excursion in terrestrial wood (Hesselbo et al., 2007a) cannot be justified by an oceanographic origin of the ${ }^{12} \mathrm{C}$ of the atmosphere (Beerling and Brentnall, 2007).

Other group of papers argues that this excursion is due to a rapid and massive release of methane from the thermal dissociation of gas hydrate contained in marine sediments, which would have rised the temperatures of the Tethys (Hesselbo et al., 2000; Kemp et al., 2005, 2006; Hesselbo et al., 2007a,b). This hypothesis has been simulated by Beerling and Brentnall (2007) by the release of $>6000 \mathrm{Gt} \mathrm{C}$, but such a massive amount rises questions about the formation, storage and release of methane gas hydrate.

The third group of papers links with the release of greenhouse gases to the igneous activity of the KarooFerrar Large Igneous Province (LIP) (Pálfy and Smith, 2000; McElwain et al., 2005; Svensen et al., 2006, 2007). McElwain et al. (2005) proposed the release of thermogenic methane as a result of the intrusion of the Karoo-Ferrar dolerites in the Gondwana coals during Toarcian, inferring first a global cooling of $2.5 \pm 0.1{ }^{\circ} \mathrm{C}$ and a greenhouse warming of $6.5 \pm 1{ }^{\circ} \mathrm{C}$. Evaluation of this mechanism fails to reproduce the supposed duration and extent of the negative $\delta^{13} \mathrm{C}$ excursion (Beerling and Brentnall, 2007). However, dating of the dolerite sills as $182.5 \mathrm{Ma}$ (around the TenuicostatumSerpentinum zonal boundary) which intruded organicrich shales of the Karoo Basin (Svensen et al., 2007), 
could be responsible of the venting of greenhouse gases (potentially 27,400 $\mathrm{Gt} \mathrm{CO}_{2}$ ), triggering the Toarcian global warming. Numerical evaluation of the last hypotheses performed by Beerling and Brentnall (2007) favours the hypothesis of hydrothermal vent complexes and deep breccia pipes by rapid intrusion of magma into coal-bearing beds and pulsed methane release due to intrusion of the organic-rich shales of the Karoo Basin.

An additional source of controversy is the comparison between the $\delta^{13} \mathrm{C}_{\text {carb }}$ and the $\delta^{13} \mathrm{C}_{\mathrm{bel}}$ curves. In the opinion of some authors, this anomaly is not recorded in belemnites (McArthur et al., 2000; van de Schootbrugge et al., 2005a,b; Wignall et al., 2005, 2006; McArthur, 2007), making the $\delta^{13} \mathrm{C}$ negative excursion widely distributed but not of global extent. In the $\delta^{13} \mathrm{C}_{\text {bel }}$ curves obtained in both the Rodiles-Santa Mera and the La Almunia-Ricla sections (Figs. 3, 7, 10 and 15c-14, 15), as well as in the $\delta^{13} \mathrm{C}_{\text {bel }}$ curve obtained in the BasqueCantabrian Basin in Northern Spain (Rosales et al., $2001 \mathrm{a}$; Fig. 15c-16), the negative anomaly is not visible. Papers favouring a global extent of the $\delta^{13} \mathrm{C}$ negative excursion argue that the isotopic signature in belemnites is influenced by other factors such as local productivity (Hesselbo et al., 2007a,b) or due to the low sampling resolution over this interval (Tremolada et al., 2005; Kemp et al., 2006).

The reason argued for the papers who maintain the absence of the $\delta^{13} \mathrm{C}$ excursion in belemnites is that these organisms, as free-swimmers, had the opportunity to migrate towards more oxygenated surrounding environments, above the pycnocline, where such excursion was not recorded (Wignall et al., 2005). However, in sections with very high TOC values such as the Yorkshire sections (Sælen et al., 1996; McArthur et al., 2000) or Dotternhausen (van de Schootbrugge et al., 2005a), isotopic studies based on belemnite calcite have been carried out.

The correlation of the Middle and Upper Toarcian $\delta^{13} \mathrm{C}_{\text {bel }}$ negative excursions recorded in this study with results from other areas is difficult, as most isotopic studies are focused on the Early Toarcian. The relative decrease of the $\delta^{13} \mathrm{C}_{\text {bel }}$ values recorded at the upper Bifrons Zone of the Spanish sections could correlate with a $\delta^{13} \mathrm{C}_{\text {carb }}$ decrease in. similar stratigraphic positions found in the UK Winterborne Kingston borehole and in $\delta{ }^{13} \mathrm{C}_{\text {org }}$ in the Mochras Borehole (Jenkyns and Clayton, 1997; Jenkyns et al., 2002), as well as in Portugal (Duarte, 1998; Duarte et al., 2004) and Italy (Morettini et al., 2002). This short-term $\delta^{13} \mathrm{C}$ negative excursion is synchronous with the maximum peak transgression recorded in both studied areas (Fig. 4) and one of the main transgressive intervals recorded in the Early Jurassic of Europe (de Graciansky et al., 1998; Gómez and Goy, 2005).

The negative $\delta^{13} \mathrm{C}_{\text {bel }}$ peak found at the late Thouarsense-early Dispansum biochrons could be of major interest due to its synchronism with a thermal peak and both related to important igneous activity. This anomaly could correlate with a decrease in $\delta^{13} \mathrm{C}_{\text {carb }}$ found by Jenkyns and Clayton (1997) in the Mochras Borehole, and with the Late Toarcian $\delta^{13} \mathrm{C}$ and $\delta^{18} \mathrm{O}$ anomalies reported by Morettini et al. (2002) in Italy.

\subsection{Timing of the Karoo-Ferrar igneous activity and mass extinction}

Pálfy and Smith (2000) located the peakEarly Toarcian mass extinction at $183 \mathrm{Ma}$, which these authors consider synchronous with the peak magmatic activity of the Gondwanan Karoo and Ferrar LIP flood basalts eruptions. Similar ages (182.5 Ma) are given by Svensen et al. (2006, 2007) for the sills and breccia pipes of the Karoo Basin.

Analysis of ${ }^{40} \mathrm{Ar} /{ }^{39} \mathrm{Ar}$ data reveal that the duration of the total magmatic interval was 8 m.y., with two brief contemporaneous major tectonomagmatic events: the Okavango dike swarm between 178.4 and $180.9 \mathrm{Ma}$, and the Shadi-Shadi lava pile between 178.0 and 180.9 Ma (Jourdan et al., 2004, 2005). Following the Geologic Time Scale 2004 (Ogg, 2004), the peaks of the Karoo magmatism are much younger than the mass extinction boundary (located now at 182.7 Ma). Comparison of both ages, the main Karoo magmatic interval seems to coincide with the latest Bifrons-early Dispansum interval. Synchronous $\delta^{13} \mathrm{C}$ and $\delta^{18} \mathrm{O}$ negative excursions, recorded at the Insigne Biochron, were observed in the two studied sections (Figs. 10 and 11).

\subsection{Positive $\delta^{13} \mathrm{C}$ excursions}

An Early Toarcian positive $\delta^{13} \mathrm{C}$ excursion has been recorded in most European sections, whether in bulk rock or belemnite carbonates, in marine organic matter, and in wood. In the studied outcrops, the positive anomaly in the belemnite carbonate and, to a lesser extent in the bulk rocks samples, has also been recorded.

Most authors are in agreement about the interpretation of this positive anomaly as the response of water masses to excess and rapid burial of large amounts of organic carbon rich in ${ }^{12} \mathrm{C}$, that led to enrichment in ${ }^{13} \mathrm{C}$ of the sediments (Jenkyns and Clayton, 1997; Schouten et al., 2000), or to removal from oceans of large amounts of isotopically light carbon as organic matter into black shales or 
methane hydrates, which leaves oceanic carbon isotopically heavy (McArthur et al., 2000).

This excursion is also present in areas were no black shale facies were deposited and a good example is the $\delta^{13} \mathrm{C}_{\mathrm{bel}}$ record obtained in the La Almunia-Ricla section. It can also be observed that the timing of the $\delta^{13} \mathrm{C}$ heaviest values does not coincide with the TOC peak values, and the timing of the $\delta{ }^{13} \mathrm{C}$ peak values does not coincide in many of the considered sections. Results shown in Figs. 10 and 15 do not support the idea that $\delta^{13} \mathrm{C}$ peak values of the positive excursion are synchronous and, as a consequence, they should not be used as a correlative level of identical stratigraphical age in sections from different faunal provinces in Europe, unless it is demonstrated with an independent method.

\subsection{Sea-level changes and mass extinction}

Many authors have argued that a strong relationship between marine mass extinction and eustatic falls of sea level exists (Newell, 1967). However, analysis of several mass extinction events and the related sea-level changes led Hallam and Wignall (1999) to conclude that majority of extinctions occur at the transgressive pulse of the transgressive-regressive couplets.

In the studied sections, as well as in most of Europe, the mass extinction boundary coincides with a transgressive interval, of which its second order cycle peak transgression is reached at the Bifrons Biochron (de Graciansky et al., 1998).

\subsection{Late Pliensbachian-Early Toarcian palaeotem- peratures and salinities}

There is a general consensus for a warm climate in the Jurassic, globally $5-10{ }^{\circ} \mathrm{C}$ warmer than present for some authors (Chandler et al., 1992; Bailey et al., 2003), and more equable conditions as compared to the present day (Hallam, 1975, 1993), but this opinion is not shared by Chandler et al., 1992.

Some Early Toarcian palaeotemperature curves, supported by good-resolution biostratigraphical subdivisions, have been obtained in the last years. Among the palaeotemperatures curves obtained from bulk carbonates, in Dotternhausen (Germany) the obtained values are unreasonably high (Fig. 16-1), ranging from 36 to

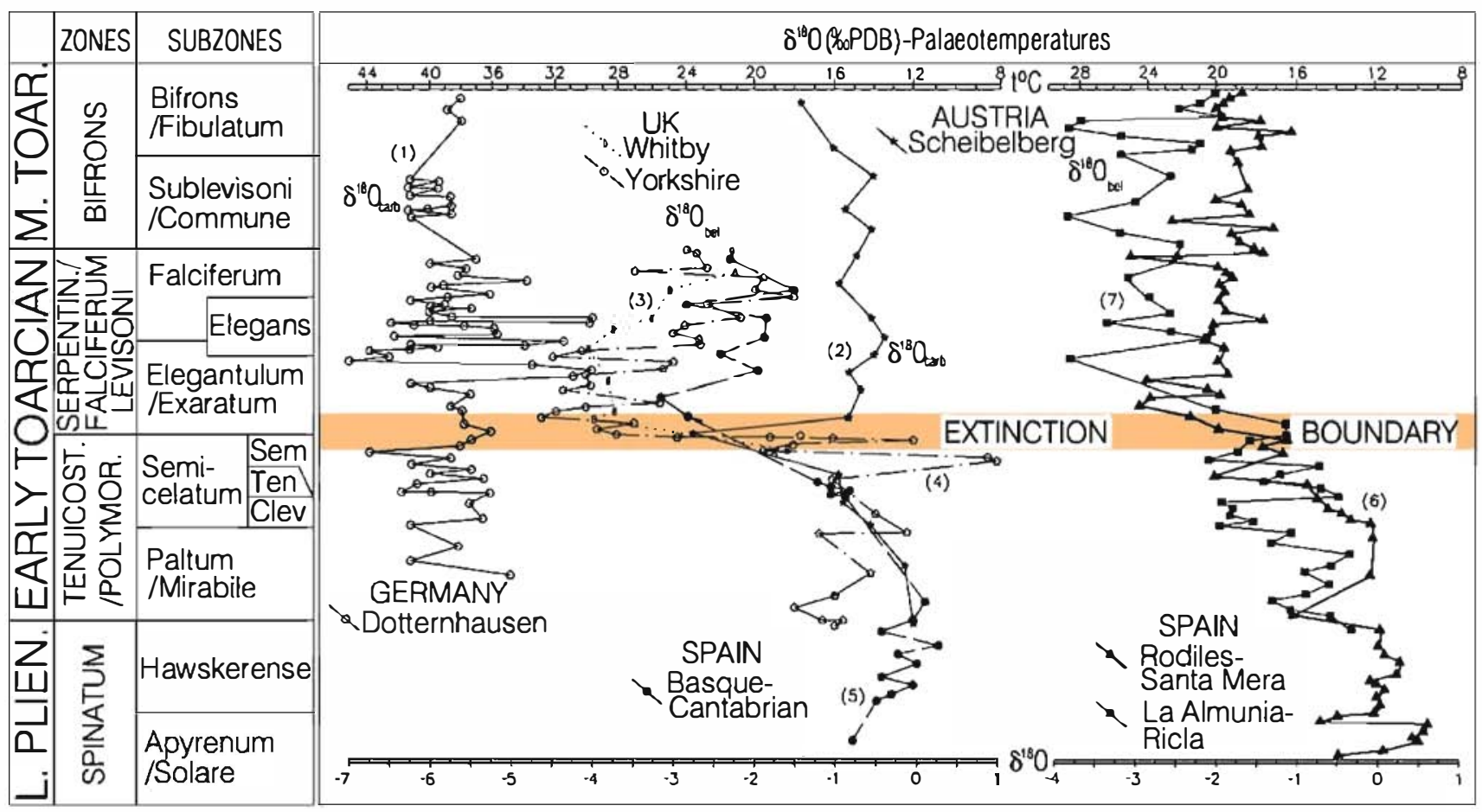

Fig. 16. Correlation and timing of the Late Pliensbachian-Early Toarcian palaeotemperature curves obtained from $\delta^{18} \mathrm{O}$. (1) Germany, Dotternhausen (Röhl et al., 2001; Schmid-Röhl et al., 2002). Palaeotemperatures have been recalculated using the Anderson and Arthur (1983) equation from the $\delta^{18} \mathrm{O}_{\text {carb }}$ values obtained by Röhl et al. (2001) in order to have values that can be compared with other curves. (2) Austria, Tirol, Scheibelberg Section (Jenkyns et al., 1991). (3) UK, Whitby (Sælen et al., 1996). Represented values are average values calculated for each stratigraphic interval covered by these authors, except for palaeotemperature values surpassing $31^{\circ} \mathrm{C}$, where a salinity correction to these was calculated by previous authors. Most of the represented palaeotemperatures at the Exaratum Biochron include salinity correction. (4) UK, Yorkshire (using the Anderson and Arthur (1983) equation; Jenkyns, 2003). (5) Northem Spain, Basque-Cantabrian Basin (Rosales et al., 2004). (6) Spain, Asturias, Rodiles-Santa Mera Section (this work). (7) Central Spain, La Almunia-Ricla Section (this work). 
$46^{\circ} \mathrm{C}$ (about 30 to $45^{\circ} \mathrm{C}$ using the equation of Anderson and Arthur, 1983). To explain the high $\delta^{18} \mathrm{O}$-based temperature obtained in the German Posidonia Shale, a decrease in salinity in the range of $2-4 \%$ in the epicontinental sea and an increase in salinity in the order of $1-3 \%$ in the Tethyan Ocean was proposed. The curve obtained at a lower latitude, in Austria (Fig. 16-2), also from bulk carbonates, shows temperatures averaging about $16^{\circ} \mathrm{C}$, which are considered as too low, not in accordance with a tropical to subtropical ocean water temperature. Röhl et al. (2001) consider a realistic surface temperature of $25-30{ }^{\circ} \mathrm{C}$ for the subtropical to tropical European Toarcian shelf.

Many authors have pointed out that whole-rock carbonates frequently do not retain their marine geochemical signal after burial diagenesis and, therefore, are not suitable for interpretation of palaeoceanographic environments (Sælen et al., 1996; Mitchell et al., 1997; Rosales et al., 2001b) concerning $\delta^{18} \mathrm{O}$ depletion, especially in organic-rich rocks (Sass et al., 1991).

In the Whitby Mudstone Formation (UK), Sælen et al. (1996) obtained an increase in temperature from an average of $18{ }^{\circ} \mathrm{C}$ in belemnites from the uppermost Tenuicostatum Zone to around $29{ }^{\circ} \mathrm{C}$ (after salinity correction) in belemnites from the Exaratum Subzone and decreasing up to $21^{\circ} \mathrm{C}$ at the Falciferum Biochron (Fig. 16-3). In the Yorkshire (UK), McArthur et al. (2000) obtained $\delta{ }^{18} \mathrm{O}_{\text {bel }}$ values which have been used to calculate palaeotemperatures, through the Anderson and Arthur (1983) equation, and compared to the curve represented by Jenkyns (2003). Although this curve (Fig. 16-4) contains some anomalous values at the upper Tenuicostatum Zone, reflecting very low temperatures $\left(8^{\circ} \mathrm{C}\right)$ and values near $33^{\circ} \mathrm{C}$ in the Exaratum Biochron, again a very important increase in temperature is recorded around the Tenuicostatum-Serpentinum zonal boundary.

The curve obtained by Rosales et al. (2004) in the Basque-Cantabrian Basin (Northern Spain) also reflects important changes in temperature (Fig. 16-5). Correlation of geochemical Upper Pliensbachian-Lower Toarcian data between Yorkshire (UK) and Germany (Bailey et al., 2003) confirms that the largest negative shift in the $\delta^{18} \mathrm{O}$ is recorded around the Tenuicostatum-Falciferum zonal boundary, where a rise in temperature of $13{ }^{\circ} \mathrm{C}$ is recorded. As this temperature change is considered very large, these authors suggest that a change in seawater $\delta^{18} \mathrm{O}$ and/or salinity also occurred. Taking the $\mathrm{Mg} / \mathrm{Ca}$ change, an increase in temperature between 6 and $7{ }^{\circ} \mathrm{C}$, accompanied by large freshening from the latest Tenuicostatum to the earliest Falciferum biochrons is estimated.
Data presented in this work show a good record of latest Pliensbachian and Toarcian palaeotemperatures (Figs. 12 and 16-6, 7). Average palaeotemperatures measured in belemnites from the uppermost Pliensbachian Spinatum Zone of about $11.6^{\circ} \mathrm{C}$ in the RodilesSanta Mera section and $12^{\circ} \mathrm{C}$ in the Basque-Cantabrian Basin (Rosales et al., 2004) can be considered low for a calculated Central Spain palaeolatitude of about $35^{\circ}$ during Toarcian (Osete et al., 2000; Fig. 14). Close coincidence of oceanic palaeotemperatures recorded in the UK and in Germany (Bailey et al., 2003) as well as in Spain, and the development of the palaeotemperatures during the Pliensbachian (Rosales et al., 2004; this work), confirm that the latest Pliensbachian and the earliest Toarcian represent a relative cooling interval, indicating icehouse conditions (Tremolada et al., 2005).

The temperatures of the Toarcian epicontinental epeiric platform started a marked recovery. At the Tenuicostatum Biochron average temperatures of $15{ }^{\circ} \mathrm{C}$ in the Rodiles-Santa Mera section and $16{ }^{\circ} \mathrm{C}$ in the $\mathrm{La} \mathrm{Al-}$ munia-Ricla section were reached. That represents a $\Delta T$ between 4 and $4.5^{\circ} \mathrm{C}$ in about 0.3 m.y., which can be considered as a moderate warming rate compared with the present day figure of $\Delta T 0.8^{\circ} \mathrm{C}$ since the mid 19th century (Bard and Frank, 2006).

Warming process was strongly accelerated around the Tenuicostatum-Serpentinum zonal boundary, as observed in all the $\delta^{18} \mathrm{O}_{\text {bel }}$ palaeotemperature curves represented in Fig. 16. During the Serpentinum and most of the Bifrons biochrons, average temperatures of $21^{\circ} \mathrm{C}$ in the Rodiles-Santa Mera section and $24{ }^{\circ} \mathrm{C}$ in the La Almunia-Ricla section were recorded. These temperatures can be considered as very reasonable for the latitude of Iberia during the Toarcian and reasonably higher than the temperatures recorded in similar latitudes of the current oceans $\left(20-21{ }^{\circ} \mathrm{C}\right.$ according to NOAA). These values are also within the realistic surface water temperatures estimated by Röhl et al. (2001).

Taking the values obtained in the studied sections, it seems that no other intervening factors like a salinity increase are needed to explain the recorded temperatures. Indeed, no significant changes in salinity have been reported in the studies of the organisms at that time in the surveyed area.

Total recorded $\Delta T$ from the earliest Serpentinum to the Bifrons biochrons is in the order of $5.7^{\circ} \mathrm{C}$ for the RodilesSanta Mera section and $7.8^{\circ} \mathrm{C}$ for the La Almunia-Ricla section. These values are in agreement with the increase of temperature estimated as reasonable by Bailey et al. (2003), who accept seawater waming of $6-7^{\circ} \mathrm{C}$, but in our case no freshening effect is needed. It is plausible that the Northwestern Europe Toarcian platforms were more 
influenced by fresh-water flux from the surrounding emerged Pangea land (Bjerrum et al., 2001), whilst the Spanish platform system, located far from the main continents, with an Iberian Massif part y flooded by the Early Toarcian transgression (Fig. 14), was not influenced by freshening and the $\delta^{18} \mathrm{O}$ belemnite ca cite signal reflects nearly exclusively the seawater pa aeotemperatures.

The Rodiles-Santa Mera area could have been subjected to certain ephemeral influx of fresh water from the Iberian Massif around the Tenuicostatum-Serpentinum boundary, giving rise to a density stratification of the upper water column, causing probably photic zone anoxia and favouring the deposition of black shale facies (Küspert, 1982; Sælen et al., 1996, 1998, 2000; Schouten et al., 2000; Röhl et al., 2001; Bailey et al., 2003; Tremolada et al., 2005).

In this model the La Almunia-Ricla section, located to the south and farther from the emerged land (Fig. 14), was not influenced by freshening and no black shale facies were deposited. Probably due to latitudinal differences, to shallower environments and speculatively to local and occasional hydrothermal venting linked with volcanic activity, recorded palaeotemperatures are normally higher in this section than in the section of Northern Spain.

No indications of a global cooling event of $2.5^{\circ} \mathrm{C}$ at the late Tenuicostatum Biochron, as interpreted by McElwain et al. (2005), has been found in the temperature curves obtained in this work and it cannot be observed in the curves from other localities (Fig. 16), as previously indicated by Wignall et al. (2005). Based on the available analyzed data, it seems that there is a general outstanding increase of seawater temperature around the Tenuicostatum-Serpentinum zonal boundary, which looks to be isochronous and coincident with the extinction boundary.

\subsection{Middle-Late Toarcian carbon isotope records and warming intervals}

In addition to the main Early-Middle Toarcian warming interval, three temperature peaks and four $\delta^{13} \mathrm{C}_{\text {bel }}$ excursions were recorded in the studied sections. A negative $\delta^{13} \mathrm{C}_{\text {bel }}$ excursion has been recognized in both sections at the Middle Toarcian late Bifrons Biochron.

The oldest thermal peak, developed during a part of the Illustris and Vitiosa biochrons, represents a $2-3{ }^{\circ} \mathrm{C}$ $\Delta T$ (Fig. 12). This warming episode is synchronous with the regressive portion of cycle LJ-3 (Fig. 4) and could be linked with a generalized shallowing of the platform but it also coincides with the major tectonomagmatic events of the Karoo Basin (Jourdan et al., 2005). This event also coincides with noteworthy changes in the biosphere, such as the renewal in the ammonite and brachiopod faunas of NW Europe and Western Tethys, reported by Joral and Goy (2000). In addition, the occurrence of a severe crisis affecting the brachiopods at the Variabilis (=Gradata) Biochron in most Western Tethys, such as in Portugal, Provence (France), Middle Atlas (Morocco), Iberian Range and Pyrenees (Spain) has also been mentioned by Almeras and Fauré (1990).

A further thermal peak has also been detected at the Insigne Subzone, starting around the ThouarsenseDispansum boundary. In the La Almunia-Ricla section, $\Delta T$ is in the order of $3{ }^{\circ} \mathrm{C}$, and in both sections the thermal peak is included within a $\delta^{13} \mathrm{C}$ negative excursion of about $1.5 \%$. Synchrony between the Karoo main magmatic activity (178-180.9 Ma) (Jourdan et al., 2005) and the age of the Thouarsense and Dispansum biochrons (178.5-180.5 Ma) (Ogg, 2004) suggests that the $\delta^{13} \mathrm{C}$ negative anomaly and the recorded warming interval could be caused by the release of volcanogenic $\mathrm{CO}_{2}$ from the Karoo LIP, which could trigger the release of other greenhouse gases.

Additional well-dated isotope curves need to be studied in other areas to test the regional or global extension of the Insigne waming peak and associated $\delta^{13} \mathrm{C}$ negative excursion. However, preliminary research in the palaeontological database indicates that noteworthy changes in the abundance and diversity of the assemblages in several faunal groups of NW Europe and Tethys are observed during this short interval. Among the nektonic organisms, the ammonites of the Phymatoceratidae family became extinct (Bécaud et al., 2005) and a notable increase in the abundances of the families Harpoceratidae, Grammoceratidae and Hammatoceratidae, and the appearance of the genus Hammatoceras has been recorded synchronously (Goy and Martínez, 1990). Among the brachiopods, a moderated increase in diversity and a notable increase in the number of specimens have been observed in the ThouarsenseDispansum zonal transition in the Iberian Range (Joral and Goy, 2000). In Western Tethys, Almeras and Fauré (1990) report a complete renewal of the brachiopods at the Thouarsense-Insigne (=Dispansum) biochrons in Provence (France) and in the Middle Atlas (Morocco). Among the foraminifers, several taxa that reached their maximum development in the Middle Jurassic had their FOD within this interval (Copestake and Johnson, 1989), some taxa disappeared (Ruget, 1985) even though some of them reappear later on, during the Late Toarcian and the Aalenian (Canales, 2001). With respect to nannoplankton, some forms have their first appearance in this interval (Perilli et al., 2004). 
The uppermost thermal peak recorded at the Levesquei Subzone has only been recorded in the $\mathrm{La}$ Almunia-Ricla section and coincides with a positive $\delta^{13} \mathrm{C}$ excursion, which is also more pronounced in this section than in Asturias. The $\Delta T$ is in the order of $2.4^{\circ} \mathrm{C}$, and this warming could favour the productivity, as reflected by the increased $\delta^{13} \mathrm{C}$ values. Finally, the Mactra Subzone positive $\delta^{13} C_{\text {bel }}$ excursion (Fig. 10) recorded in the Iberian Range, does not have an equivalent in Asturias. According to Holser (1997), Kump (1991) and Kump and Arthur (1999), it could be interpreted as a transient shift caused by occasional short-term changes of biological productivity in the surface photic zone.

\section{Conclusions}

Comparison of the available Late Pliensbachian and Early Toarcian palaeotemperature curves, the recorded perturbations of the carbon cycle, the organic-rich deposits related to the ETOAE and the sequence of extinctions recorded during this time interval show that there is a narrow correlation between all those phenomena.

From the latest Pliensbachian cooling interval, the first rapid increment of seawater temperature started around the Pliensbachian-Toarcian boundary, marking the first step of a warming event and the beginning of the main extinction. Many taxa disappeared around this boundary, but the main extinction was progressively developed at the Tenuicostatum Biochron. As increase in temperature and additional environmental changes developed, more species progressively disappeared, marking the extinction interval. Determination of the causes of this waming process constitutes a major objective of research.

During this initial warming interval, enhanced evaporation probably created a more humid climate, acquiring a monsoon-like type of regime (Chandler et al., 1992). Due to the tectonic activity and its interaction with the generalized sea-level rise, sub-basins started to differentiate which, together with the enhanced rainfall and perhaps with changes in the ocean circulation, contributed to the generation of water mass salinity stratification which conducted to the dysoxic-anoxic conditions recorded in some of these sub-basins. Significant amounts of organic carbon accumulated below the redox boundary, and bacterial degradation produced isotopically light $\mathrm{CO}_{2}$. Seasonal reversal produced a mix between bottom and surface waters and surface organisms recycled the light $\mathrm{CO}_{2}$, resulting in organic matter depleted in heavy carbon (Küspert, 1982). As a consequence, organic-rich deposits commonly show an associated negative $\delta^{13} \mathrm{C}$ excursion in marine bulk carbonate and organic matter which cannot explain the major Early Toarcian excursion. Predominance of local oxygen-depleted environments forced regional biotic crisis which can be locally misinterpreted as mass extinction events. However, they are diachronous and not of global extent.

Establishment of anoxic conditions could be synchronous at the sub-basin scale, but the onset and the end of anoxic conditions, as well as the accompanying effects, were diachronous among the different subbasins. Anoxic conditions and the associated negative $\delta{ }^{13} \mathrm{C}$ anomaly started and finished in some areas at the Tenuicostatum Biochron (e.g. the Umbria-Marche Basin in Italy, the Subbetic and the Basque-Cantabrian Basin in Spain). However, in some other areas like in Northern UK, Southern Germany, and Northem Spain (Asturias), anoxia and accompanying effects started at the latest Tenuicostatum Biochron, and in Southern France anoxic facies were not developed until the early Falciferum Biochron. Negative $\delta^{13} \mathrm{C}$ excursion associated to euxinic conditions is as diachronous as the organic-rich facies, and in many sub-basins it is the first carbon isotope signal recorded in bulk marine carbonate and organic matter.

Throughout the Tenuicostatum Biochron, warming continued, and a $\Delta T$ between 4 and $4.5^{\circ} \mathrm{C}$, as archived in our dataset, was reached. A new rapid rise in seawater palaeotemperatures from the latest Tenuicostatum to the Serpentinum-Bifrons biochrons, in the order of $\Delta T$ $5.7{ }^{\circ} \mathrm{C}$ to $7.8^{\circ} \mathrm{C}$ as calculated from our dataset, or $7-$ $13{ }^{\circ} \mathrm{C}$ as mentioned by Bailey et al. (2003) and Jenkyns (2003), was recorded.

Causes of these warming intervals are still under debate, but the rapid warming that occurred around the Tenuicostatum-Serpentinum zonal boundary, which was synchronously recorded at least in the different areas of Western Europe, represented a dramatic change in the already degraded environmental conditions that seriously damaged the populations of diverse organisms. The crisis affected the base of the trophic chain as well as many benthic but also nektonic organisms. The significant accumulated increase in temperature probably surpassed the temperature tolerance threshold of numerous species that thrived in the cooler waters of the late Pliensbachian, provoking the gradual massive mortality and disappearance of numerous taxa worldwide. The prevalence of southwards winds and currents in the Transcontinental Laurasian Seaway (Chandler et al., 1992; Bjenum et al., 2001) strongly complicated or even impeded the migration of the benthos towards cooler waters located north of the Iberian Massif. This data are supported by the finding of predominant 
southwards migration routes in this area for the Early Toarcian ostracods, as shown by Arias (2006, 2007).

Additional warming intervals are recognized at the late Variablis Biochron $\left(\Delta T 2-3{ }^{\circ} \mathrm{C}\right)$ and at the early Dispansum Biochron $\left(\Delta T 3{ }^{\circ} \mathrm{C}\right)$ which was accompanied by a $\delta^{13} C_{\text {bel }}$ excursion of about $-1.5 \%$. Available data suggest that some significant effects on the benthic and nektonic faunas were caused by these climate changes, but further research efforts oriented to the acquisition of additional data are required.

\section{Aknowledgements}

This research work was financed by project CGL200501765/BTE of the Spanish Ministerio de Educacion y Ciencia. We gratefully acknowledge F. Surlyk, P. Wignall and an anonymous reviewer for their valuable comments and constructive reviews.

\section{References}

Aberhan, M., Fürsich, F.T., 1997. Diversity analysis of Lower Jurassic bivalves of the Andean Basin and the Pliensbachian-Toarcian mass extinction. Lethaia 29, 181-195.

Almeras, Y., Fauré, P., 1990. Histoire des brachiopodes liasiques dans la Téthys occidentale: les crises et l'écologie. Cah. Univ. Cathol. Lyon, Sér. Sci. vol. 4, 1-12.

Anderson, T.F., Arthur, M.A., 1983. Stable isotopes of oxygen and carbon and their application to sedimentologic and paleoenvironmental problems. In: Arthur, M.A. (Ed.), Stable isotopes in sedimentary geology. SEPM Short Course, vol. 10, pp. 1-1-1-151.

Arias, C.F., 1995. Los ostrácodos del Toarciense inferior en la Cordillera Ibérica. Ph. D. Thesis. Fac. C. Geológicas. Univ. Complutense Madrid, Spain.

Arias, C.F., 1996. Ostracods. In: Ureta, S. (Ed.), The Toarcian in the sector located between La Almunia de Doña Godina and Ricla. 1st Toarcian and 4th Aalenian working groups meeting. Fieldtrip Iberian Range, pp. 18-20.

Arias, C., 2006. Northern and southern hemisphere ostracod palaeobiogeography during the Early Jurassic: possible migration routes. Palaeogeogr. Palaeoclimatol. Palaeoecol. 233, 63-95.

Arias, C., 2007. Pliensbachian-Toarcian ostracod biogeography in NW Europe: evidence for water mass structure evolution. Palaeogeogr. Palaeoclimatol. Palaeoecol. 251, 398-421.

Arias, C.F., Comas-Rengifo, M.J., Goy, A., Herrero, C., Ruget, C., 1992. Variations dans les associations de brachiopodes, foraminifères et ostracodes du Toarcien basal dans un secteur central de la Cordillère Ibérique. Un example dans la "Rambla del Salto" (Teruel, Espagne). Cah. Univ. Cathol. Lyon, Sér. Sci. 5, 5-25.

Aurell, M., Robles, S., Bádenas, B., Rosales, I., Quesada, S., Meléndez, G., García-Ramos, J.C., 2003. Transgressive-regressive cycles and Jurassic palaeogeography of northeast Iberia. Sediment. Geol. 162, 239-271.

Bailey, T.R., Rosenthal, Y., McArthur, J.M., van de Schootbrugge, B., Thirlwall, M.F., 2003. Paleoceanographic changes of the Late Pliensbachian-Early Toarcian interval: a possible link to the genesis of an Oceanic Anoxic event. Earth Planet. Sci. Lett. 212, 307-320.
Bard, E., Frank, M., 2006. Climate change and solar variability: what's new under the sun? Earth Planet. Sci. Lett. 248, 1-14.

Barnes, C., Hallam, A., Kaljo, D., Kauffrnan, E.G., Walliser, O.H., 1996. Global event stratigraphy. In: Walliser, O.H. (Ed.), Global Events and Event Stratigraphy in the Phanerozoic. Springer-Verlag, pp. 319-327.

Bartolini, A., Nocchi, M., Baldanza, A., Parisi, G., 1992. Benthic life during the Early Toarcian anoxic event in the Southwestern Tethyan Umbria-Marche Basin, Central Italy. Studies in Benthic Foraminifera, Benthos'90. Tokai University Press, Sendai, Japan, pp. 323-338.

Bassoullet, J.P., Baudin, F., 1994. Le Toarcien inférieur: une période de crise dans les bassins et sur les plate-formes carbonatées de l'Europe du Nord-Ouest et de la Téthys. Geobios, Mém. Spec. 17, 645-654.

Bassoullet, J.P., Lachkar, G., Baudin, F., Benshili, K., Blanc, P., Boutakiout, M., Depêche, F., Elmi, S., Ruget, C., 1991. Stratigraphie intégrée dans le Toarcien du Maroc (rides sud-rifaines et Moyen Atlas). Bull. Soc. Géol. Fr. 162, 825-839.

Bassoullet, J.P., Elmi, S., Poisson, A., Cecca, F., Bellion, Y., Guiraud, R., Baudin, F., 1993. Mid Toarcian (184 to $182 \mathrm{Ma}$ ). In: Dercourt, J., Ricou, L.E., Vrielynck, B. (Eds.), Atlas Tethys Palaeoenvironmental Maps. BEICIP-FRANLAB, Rueill-Malmaison, France, pp. 63-80.

Bécaud, M., Rulleau, L., Elmi, S., 2005. Le renouvellement des faunes d'armmonites à la limite Toarcien moyen-Toarcien supérieur dans les domaines du nord-ouest de l'Europe et de la Téthys occidentale. Bull. Soc. Géol. Fr. 176, 23-35.

Beerling, D.J., Brentnall, S.J., 2007. Numerical evaluation of mechanisms driving Early Jurassic changes in global carbon cycling. Geology 35, 247-250.

Beerling, D.J., Lomas, M.R., Gröcke, D.R., 2002. On the nature of methane gas-hydrate dissociation during the Toarcian and Aptian oceanic anoxic event. Am. J. Sci. 302, 28-49.

Bermad, J., 1996. Bivalves. In: Ureta, S. (Ed.), The Toarcian in the sector located between La Almunia de Doña Godina and Ricla. 1st Toarcian and 4th Aalenian working groups meeting. Fieldtrip Iberian Range, pp. 14-15.

Bjerrum, C.J., Surlyk, F., Callomon, J.H., Slingerland, R.L., 2001 Numerical paleoceanographic study of the Early Jurassic transcontinental Laurasian Seaway. Paleoceanography 16, 390-404.

Boomer, I., Ainsworth, N.R., Exton, J., 1998. A re-examination of the Pliensbachian and Toarcian Ostracoda of Zambujal, west-central Portugal. J. Micropalaeontol. 17, 1-14.

Boutakiout, M., Elmi, S., 2000. Tectonic and eustatic controls during the Lower and Middle Jurassic of the South Rif Ridge (Morocco) and their importance for the foraminifera-communities. GeoRes. Forum 1-2, 237-248.

Braga, J.C., Comas-Rengifo, M.J., Goy, A., Rivas, P., Yébenes, A., 1988 El Lías inferior y medio en la zona central de la Cuenca VascoCantábrica (Camino, Santander). Cienc. Tierra, Geol. 11, 17-45.

Bucefalo Palliani, R., Cirilli, S., Mattioli, E., 1998. Phytoplankton response and geochemical evidence of the lower Toarcian relative sea level rise in the Umbria-Marche basin (Central Italy). Palaeogeogr. Palaeoclimatol. Palaeoecol. 142, 33-50.

Canales, M.L., 2001. Los foraminíferos del Aaleniense (Jurásico Medio) en la Cuenca Vasco-Cantábrica ( $\mathrm{N}$ de España). Rev. Esp. Micropaleontol. 33, 253-438.

Cecca, F., Macchioni, F., 2004. The two Early Toarcian (Early Jurassic) extinction events in ammonoids. Lethaia 37, 35-56.

Chandler, M.A., Rind, D., Ruedy, R., 1992. Pangaean climate during the Early Jurassic: GCM simulations and the sedimentary record of paleoclimate. Geol. Soc. Amer. Bull. 104, 543-559.

Cobianchi, M., Picotti, V., 2001. Sedimentary and biological response to sea-level and palaeoceanographic changes of a Lower-Middle 
Jurassic Tethyan platform margin (Southem Alps, Italy). Palaeogeogr. Palaeoclimatol. Palaeoecol. 169, 219-244.

Comas-Rengifo, M.J., Goy, A., Rivas, P., Yébenes, A., 1988. El Toarciense en Castillo Pedroso (Santander). Cienc. Tierra, Geol. 11, 63-71.

Comas-Rengifo, M.J., Gómez, J.J., Goy, A., Arias, C.F., Bemad, J., García Joral, F., Herrero, C., Martínez, G., Perilli, N., 1996. The Toarcian in the Rambla del Salto (Sierra Palomera) section. In: Ureta, S. (Ed.), 1st Toarcian and 4th Aalenian working groups meeting. Fieldtrip Iberian Range, pp. 27-48.

Copestake, P., Johnson, B., 1989. The Hettangian to Toarcian (Lower Jurassic). In: Jenkyns, D.G., Murray, J.W. (Eds.), Stratigraphical Atlas of Fossil Foraminifera, 2nd Edition. British Micropaleontological Society Series. Ellis Horwood Limited, pp. 129-188.

Cubaynes, R., Fauré, P., 1981. Les schistes carton du Quercy, témoins de la transgression Toarcienne. Doc. Bur. Rech. Géol. Min. 110, 215-230.

Dean, W.T., Donovan, D.T., Howarth, M.K., 1961. The Liassic Ammonite zones and subzones of the North-West European Province. Bull. Br. Mus. Nat. Hist. 4, 437-505.

de Graciansky, P.C., Jacquin, T., Hesselbo, S.P., 1998. The Ligurian Cycle: an overview of Lower Jurassic 2nd-order transgressive/ regressive facies cycles in western Europe. In: de Graciansky, P.C., Hardenbol, J., Jacquin, T., Vail, P.R. (Eds.), Mesozoic and Cenozoic Sequence Stratigraphy of European Basins. SEMP Spec. Publ., vol. 60, pp. 467-479.

Duarte, L.V., 1998. Clay minerals and geochemical evolution in the Toarcian-Lower Aalenian of the Lusitanian Basin (Portugal). Cuad. Geol. Ibér. 24, 69-98.

Duarte, L., Perilli, N., Dino, R., Rodrigues, R., Paredes, R., 2004. Lower to Middle Toarcian from the Coimbra Region (Lusitanian Basin, Portugal): sequence stratigraphy, calcareous nannofossils and stableisotope evolution. Riv. Ital. Paleontol. Stratigr. 110, 115-127.

Elmi, S., Goy, A., Mouterde, R., Rivas, P., Rocha, R.B., 1989. Correlaciones bioestratigráficas en el Toarciense de la Península Ibérica. Cuad. Geol. Ibér. 13, 265-277.

Elmi, S., Gabilly, J., Mouterde, R., Rulleau, L., Rocha, R.B., 1994. L'étage Toarcien de l'Europe et de la Téthys: divisions et corrélations. Geobios, Mém. Spéc. 17, 149-159.

Elmi, S., Dommerges, J.-L., Rulleau, L., Gabilly, J., Mouterde, R., 1997. Toarcien-Groupe Français d'Étude du Jurassique- Biostratigraphie du Jurassique ouest-européen et méditerranéen: Zonations parallèles et distribution des invertébrés et microfossiles. In: Cariou, E., Hantzpergue, P. (Eds.), Bull. Centre Rech., vol. 17. Elf Exploration Production, pp. 120-125.

Erba, E., 2004. Calcareous nannofossils and Mesozoic oceanic anoxic events. Mar. Micropaleontol. 52, 85-106.

Gahr, M.E., 2005. Response of Lower Toarcian (Lower Jurassic) macrobenthos of the Iberian Peninsula to sea level changes and mass extinction. J. Iber. Geol. 31, 197-215.

García Joral, F., Goy, A., 1996. Brachiopods. In: Ureta, S. (Ed.), The Toarcian in the sector located between La Almunia de Doña Godina and Ricla. 1st Toarcian and 4th Aalenian working groups meeting. Fieldtrip Iberian Range, pp. 12-14.

Golonka, J., 2006. Late Triassic and Early Jurassic palaeogeography of the World. Palaeogeogr. Palaeoclimatol. Palaeoecol. 244, 297-307.

Gómez, J.J., Goy, A., 2000. Definition and organization of limestonemarls cycles in the Toarcian of the Northern and East-Central part of the Iberian Subplate (Spain). GeoRes. Forum 6, 301-310.

Gómez, J.J., Goy, A., 2005. Late Triassic and Early Jurassic palaeogeographic evolution and depositional cycles of the Western Tethys Iberian platform system (Eastern Spain). Palaeogeogr. Palaeoclimatol. Palaeoecol. 222, 77-94.
Goričan, Š., Šmuc, A., Baumgartner, P.O., 2003. Toarcian Radiolaria from Mt. Mangart (Slovenian-Italian border) and their paleoecological implications. Mar. Micropaleontol. 49, 275-301.

Goy, A., Martínez, G., 1990. Biozonación del Toarciense en el área de La Almunia de Doña Godina-Ricla (Sector Central de la Cordillera Ibérica). Cuad. Geol. Ibér. 14, 11-53.

Goy, A., Martínez, G., Arias, C.F., Bernad, J., García Joral, F., Gómez, J.J., Herrero, C., Perilli, N., Ureta, S., 1996. The Toarcian in the sector located between La Almunia de Doña Godina and Ricla. In: Ureta, S. (Ed.), 1st Toarcian and 4th Aalenian working groups meeting. Fieldtrip Iberian Range, pp. 3-23.

Goy, A., Gómez, J.J., Herrero, C., Suárez-Vega, L.C., 1997. El Toarciense inferior en el sector comprendido entre Rodiles y Lastres (Asturias). 4th Cong. Jurásico de España. Alcañiz, Zaragoza, España, pp. 81-82.

Goy, A., Comas-Rengifo, M.J., Arias, C., Gómez, J.J., González, J.A., Herrero, C., Palencia, A., Perilli, N., Rodrigo, A., 2006. The Pliensbachian/Toarcian boundary in the Almonacid de la Cuba section (Iberian Range, Spain). Volumina Jurassica 4, 164-166.

Hallam, A., 1961. Cyclothems, transgressions and faunal changes in the Lias of north west Europe. Trans. Edinb. Geol. Soc. 18, 132-174.

Hallam, A., 1975. Jurassic Environments. Cambridge University Press, Cambridge, UK.

Hallam, A., 1986. The Pliensbachian and Tithonian extinction events. Nature 319, 765-768.

Hallam, A., 1987. Radiations and extinctions in relation to environmental change in the marine Jurassic of north west Europe. Paleobiol. 13, $152-168$.

Hallam, A., 1988. A re-evaluation of Jurassic eustasy in the light of new data and the revised Exxon curve. In: Wilgus, C.K., Hastings, B.S., Kendall, C.G., Posamentier, H.W., Ross, C.A., Van Wagoner, J.C. (Eds.), Sea-level changes: an integrated approach. Soc. Econ. Paleontol. Mineral. Spec. Publ., 42, pp. 261-273.

Hallam, A., 1992. Phanerozoic sea-level changes. Columbia University Press, New York.

Hallam, A., 1993. Jurassic climates as inferred from the sedimentary and fossil record. Phil. Trans. Roy. Soc. Lond. 341, 287-296.

Hallam, A., 1996. Major bio-events in the Triassic and Jurassic. In: Walliser, O.H. (Ed.), Global Events and Event Stratigraphy in the Phanerozoic. Springer-Verlag, pp. 265-283.

Hallam, A., 1997. Estimates of the amount and rate of sea-level change across the Rhaetian-Hettangian and Pliensbachian-Toarcian boundaries (latest Triassic to early Jurassic). J. Geol. Soc. Lond. 154, $773-779$.

Hallam, A., 2006. Facies and carbon isotope studies in southem Tibet suggest that the Toarcian extinction was diachronous. Volumina Jurasica 4, 168 .

Hallam, A., Wignall, P.B., 1999. Mass extinctions and sea-level changes. Earth-Sci. Rev. 48, 217-250.

Hardenbol, J., Thierry, J., Farley, M.B., Jacquin, Th., de Graciansky, P.C., Vail, P.R., 1998. Mesozoic and Cenozoic sequence chronostratigraphy framework of European Basins. Jurassic chronostratigraphy. In: De Graciansky, P.C., Hardenbol, J., Jacquin, Th., Vail, P. (Eds.), Mesozoic and Cenozoic Sequence Stratigraphy of European Basins. SEMP Spec. Publ., vol. 60, pp. 3-13.

Harries, P.J., Little, C.T.S., 1999. The early Toarcian (Early Jurassic) and the Cenomanian-Turonian (Late Cretaceous) mass extinctions: similarities and contrasts. Palaeogeogr. Palaeoclimatol. Palaeoecol. $154,39-66$.

Hart, M.B., Hylton, M.D., Oxford, M.J., Price, G.D., Hudson, W., Smart, C.W., 2003. The search for the origin of the planktic Foraminifera. J. Geol. Soc. Lond. 160, 341-343. 
Hesselbo, S.P., Jenkyns, H.C., 1995. A comparison of the Hettangian to Bajocian successions of Dorset and Yorkshire. In: Taylor, P.D. (Ed.), Fied Geology of the British Jurassic. Geol. Soc. Lond., pp. 105-150.

Hesselbo, S.P., Gröcke, D.R., Jenkyns, H.C., Bjerrum, C.J., Farrimond, P., Morgans Bell, H.S., Green, O.R., 2000. Massive dissociation of gas hydrate during a Jurassic oceanic anoxic event. Nature 406, 392-395.

Hesselbo, S.P., Jenkyns, H.C., Duarte, L.V., Oliveira, L.C.V.r, 2007 a. Carbon-isotope record of the Early Jurassic (Toarcian) Oceanic Anoxic Event from fossil wood and marine carbonate (Lusitanian Basin, Portugal). Earth Planet. Sci. Lett. 253, 455-470.

Hesselbo, S.P., Jenkyns, H.C., Duarte, L.V.r., Oliveira, L.C.V.., 2007b. Reply to comment on "Carbon-isotope record of the Early Jurassic (Toarcian) Oceanic Anoxic Event from fossil wood and marine carbonate (Lusitanian Basin, Portugal)". Earth Planet. Sci. Lett $259,640-641$.

Hollander, D.J., Bessereau, G., Belin, S., Huc, A.Y., Houzay, J.P., 1991. Organic matter in the early Toarcian shales, Paris Basin, France: a response to environmental change. Rev. Inst. Fr. Pét. 46, 543-562.

Holser, W.T., 1997. Geochemical events documented in inorganic carbon isotopes. Palaeogeogr. Palaeoclimatol. Palaeoecol. 132, 173-182.

Howarth, M.K., 1962. The Jet Rock Series and the Alum Shale Series of the Yorkshire coast. Proc. Yorks. Geol. Soc. 33, 381-422.

Howarth, M.K., 1973. The stratigraphy and ammonite fauna of the Upper Liassic Grey Shales of the Yorkshire coast. Bull. Br. Mus. Nat. Hist. 24, 235-277.

Howarth, M.K., 1992. The ammonite family hildoceratidae in the Lower Jurassic of Britain. Part one. Monogr. Palaeontogr. Soc. Lond. 2, 107-200.

Hylton, M.D., Hart, M.B., 2000. Benthic foraminiferal response to Pliensbachian-Toarcian (Lower Jurassic) sea-level change and oceanic anoxia in NW Europe. GeoRes. Forum 6, 455-462.

Jenkyns, H.C., 1985. The early Toarcian and Cenomanian-Turonian anoxic events in Europe: comparisons and contrasts. Geol. Rundsch. 74, 505-518.

Jenkyns, H.C., 1988. The early Toarcian (Jurassic) anoxic event: stratigraphic, sedimentary and geochemical evidence. Am. J. Sci. 288, 101-151.

Jenkyns, H.C., 1999. Mesozoic anoxic events and palaeoclimate. Zbl. Geol. Paläontol. 7-9, 943-949.

Jenkyns, H.C., 2003. Evidence for rapid climate change in the Mesozoic-Palaeogene greenhouse world. Phil. Trans. Roy. Soc. Lond. A 361, 1885-1916.

Jenkyns, H.C., Clayton, C.J., 1986. Black shales and carbon isotopes in pelagic sediments from the Tethyan Lower Jurassic. Sedimentology $33,87-106$.

Jenkyns, H.C., Clayton, C.J., 1997. Lower Jurassic epicontinental carbonates and mudstones from England and Wales: chemostratigraphic signals and the early Toarcian anoxic event. Sedimentology 44, 687-706.

Jenkyns, H.C., Géczy, B., Marshall, J.D., 1991. Jurassic manganese carbonates of central Europe and the early Toarcian anoxic event. J. Geol. 99, 137-149.

Jenkyns, H.C., Gale, A.S., Corfield, R.M., 1994. Carbon- and oxygenisotope stratigraphy of the English Chalk and Italian Scaglia and its palaeoclimatic significance. Geol. Mag. 131, 1-34.

Jenkyns, H.C., Gröcke, D., Hesselbo, S.P., 2001. Nitrogen isotope evidence for water mass denitrification during the early Toarcian Oceanic Anoxic Event. Paleoceanography 16, 593-603.

Jenkyns, H.C., Jones, C.E., Gröcke, D.R., Hesselbo, S.P., Parkinson, D.N., 2002. Chemostratigraphy of the Jurassic System: applica- tion, limitations and implications for palaeoceanography. J. Geol. Soc. Lond. 159, 351-378.

Jiménez, A.P., Jiménez de Cisneros, C., Rivas, P., Vera, J.A., 1996. The Early Toarcian anoxic event in the Westemmost Tethys (Subbetic): paleogeographic and paleobiogeographic significance. J. Geol. 104, 399-416.

Joral, F.G., Goy, A., 2000. Stratigraphic distribution of Toarcian brachiopods from the Iberian range (Spain) and its relation to depositional sequences. GeoRes. Forum 6, 381-386.

Jourdan, F., Féraud, G., Bertrand, H., Kampunzu, A.B., Tshoso, G., Le Gall, B., Tiercelin, J.J., Capiez, P., 2004. The Karoo triple junction questioned: evidence from Jurassic and Proterozoic ${ }^{40} \mathrm{Ar} /{ }^{39} \mathrm{Ar}$ ages and geochemistry of the giant Okavango dyke swarm (Bostwana). Earth Planet. Sci. Lett. 222, 98-1006.

Jourdan, F., Féraud, G., Bertrand, H., Kampunzu, A.B., Tshoso, G., Watkeys, M.K., Le Gall, B., 2005. Karoo large igneous province: Brevity, origin and relation to mass extinction questioned by new ${ }^{40} \mathrm{Ar}{ }^{39} \mathrm{Ar}$ age data. Geology 33, 745-748.

Kauffman, E.G., Erwin, D.H., 1995. Surviving mass extinctions. Geotimes 14, 14-17.

Kemp, D.B., Coe, A.L., Cohen, A.S., Schwark, L., 2005. Astronomical pacing of methane release in the Early Jurassic period. Nature 437, 396-399.

Kemp, D.B., Coe, A.L., Cohen, A.S., Schwark, L., 2006. Palaeoceanography: methane release in the Early Jurassic period (Reply) Nature 441, E5-E6.

Kump, L.R., 1991. Interpreting carbon-isotope excursions: Strangelove oceans. Geology 19, 299-302.

Kump, L.R., Arthur, M.A., 1999. Interpreting carbon-isotope excursions: carbonates and organic matter. Chem. Geol. 161, $181-198$

Küspert, W., 1982. Environmental changes during oil shale deposition as deduced from stable isotope ratios. In: Einsele, G., Seilacher, A. (Eds.), Cyclic and Event Stratification. Springer, New York, pp. 482-501.

Little, C.T.S., Benton, M.J., 1995. Early Jurassic mass extinction: a global long-term event. Geology 23, 495-498.

Macchioni, F., 2002. Myths and legends in the correlation between the Boreal and Tethys. Implications on the dating of the Oceanic Anoxic Event in Lower Toarcian age OAE and on the mass extinction of the Lower Toarcian. Geobios, Mém. Spéc., vol. 35, pp. 150-164.

Macchioni, F., Cecca, F., 2002. Biodiversity and biogeography of middle-late Liassic ammonoids: implications for the early Toarcian mass extinction. Geobios, Mém. Spéc. 24, 165-175.

Mailliot, S., Mattioli, E., Guex, J., Pittet, B., 2006. The Early Toarcian anoxia, a synchronous event in the Western Tethys? An approach by quantitative biochronology (Unitary Associations), applied on calcareous nannofossils. Palaeogeogr. Palaeoclimatol. Palaeoecol. 240, 562-586.

Mattioli, E., Pittet, B., Bucefalo Palliani, R., Röhl, H.J., Schmid-Röhl, A., Morettini, E., 2004. Phytoplankton evidence for the timing and correlation of palaeoceanographical changes during the early Toarcian oceanic anoxic event (Early Jurassic). J. Geol. Soc. Lond. 161, 685-693.

McArthur, J.M., 2007. Comment on "Carbon-isotope record of the Early Jurassic (Toarcian) Oceanic Anoxic Event from fossil wood and marine carbonate (Lusitanian Basin, Portugal)". by Hesselbo, S.P., Jenkyns, H.C., Duarte, L.V., Oliveira, L.C.V. Earth Planet. Sci. Lett 259, 634-639.

McArthur, J.M., Donovan, D.T., Thirlwall, M.F., Fouke, B.W., Mattey, D., 2000. Strontium isotope profile of the early Toarcian 
(Jurassic) oceanic anoxic event, the duration of ammonite biozones, and belemnite palaeotemperatures. Earth Planet. Sci. Lett. 179, 269-285.

McArthur, J.M., Doyle, P., Leng, M.J., Reeves, K., Williams, T., García-Sanchez, R., Howart, R.J., 2007. Testing palaeo-environmental proxies in Jurassic belemnites: $\mathrm{Mg} / \mathrm{Ca}, \mathrm{Sr} / \mathrm{Ca}, \mathrm{Na} / \mathrm{Ca}$ and $\delta^{13}$ C. Palaeogeogr. Palaeoclimatol. Palaeoecol. 252, 464-480.

McElwain, J.C., Wade-Murphy, J., Hesselbo, S.P., 2005. Changes in carbon dioxide during an oceanic anoxic event linked to intrusion into Gondwana coals. Nature 435, 479-482.

Mitchell, S.F., Ball, J.D., Crowley, S.F., Marshall, J.D., Paul, C.R.C., Veltkamp, C.J., Samir, A., 1997. Isotope data from Cretaceous chalks and foraminifera: environmental or diagenetic signals? Geology 25, 691-694.

Monaco, P., Nocchi, M., Ortega-Huertas, M., Palomo, I., Martínez, F., Chiavini, G., 1994. Depositional trends in the Valdorbia Section (Central Italy) during the Early Jurassic, as revealed by micropaleontology, sedimentology and geochemistry. Eclogae geol. Helv. 87, 157-223.

Morettini, E., Santantonio, M., Bartolini, A., Cecca, F., Baumgartner, P.O., Hunziker, J.C., 2002. Carbon isotope stratigraphy and carbonate production during the Early-Middle Jurassic: examples from the Umbria-Marche-Sabina Apennines (central Italy). Palaeogeogr. Palaeoclimatol. Palaeoecol. 184, 251-273.

Myers, K.J., Wignall, P.B., 1987. Understanding Jurassic organic-rich mudrocks-new concepts using gamma-ray spectrometry and palaeoecology: an example from the Kimmeridge Clay of Dorset and the Jet Rock of Yorkshire. In: Leggett, J.K., Zuffa, G.G. (Eds.), Marine clastic sedimentology. Graham and Trotman, London, UK, pp. 172-189.

Newell, N.D., 1967. Revolutions in the history of life. Geol. Soc. Am., Spec. Pap. 89, 63-91.

Nikitenko, B.L., Shurygin, B.N., 1992. Lower Toarcian black shales and Pliensbachian-Toarcian crisis of the biota of Siberian paleoseas. In: Thurston, D.K., Fujita, K. (Eds.), Proc. Int. Conf. Artic Margins 39-44.

NOAA, 2007. http://www.noaa.gov/cgi-biu/oc5/WDA SF/woa05f.pl.

Nocchi, M., Bartolini, A., 1994. Investigation on Late Dormerian-Early Toarcian Lagenina and Glomospirella assemblages in the UmbriaMarche Basin (Central Italy). Geobios, Mém. Spéc. 17, 689-699.

O'Brien, N.R., 1990. Significance of lamination in Toarcian (Lower Jurassic) shales from Yorkshire, Great Britain. Sediment. Geol. 67, 25-34.

Ogg, J.G., 2004. The Jurassic period. In: Gradstein, F.M., Ogg, J.G., Smith, A. (Eds.), A Geologic Time Scale 2004. Cambridge University Press, pp. 307-343.

Osete, M.L., Villalaín, J.J., Osete, C., Gialanella, P.R., 2000. Evolución de Iberia durante el Jurásico a partir de datos paleomagnéticos. Geotemas 1, 117-119.

Osete, M.L., Gialanella, P.R., Gómez, J.J., Villalaín, J.J., Goy, A., Heller, F., 2007. Magnetostratigraphy of Early-Middle Toarcian expanded sections from the Iberian Range (central Spain). Earth Planet. Sci. Lett. 259, 319-332.

Page, K.N., 2003. The Lower Jurassic of Europe: its subdivision and correlation. Geol. Surv. Den. Greenl. Bull. 1, 23-59.

Page, K.N., 2004. A sequence of biohorizons for the Subboreal Province Lower Toarcian in northern Britain and their correlation with a Submediterranean standard. Riv. Ital. Paleontol. Stratigr. 110, 109-114.

Pálfy, J., Smith, P.L., 2000. Synchrony between Early Jurassic extinction, oceanic anoxic event, and the Karoo-Ferrar flood basalt volcanism. Geology 28, 747-750.
Parisi, G., Ortega-Huertas, M., Nocchi, M., Palomo, I., Monaco, P., Martínez, F., 1996. Stratigraphy and geochemical anomalies of the early Toarcian oxygen-poor interval in the Umbria-Marche Apennines (Italy). Geobios 29, 469-484.

Perilli, N., Comas-Rengifo, M.J., Goy, A., 2004. Calibration of the Pliensbachian-Toarcian calcareous nannofossil zone boundaries based on ammonites (Basque-Cantabrian area, Spain). Riv. Ital. Paleontol. Stratigr. 110, 97-107.

Pettinelli, R., Nocchi, M., Parisi, G., 1997. Late PliensbachianToarcian biostratigraphy and environmental interpretations in the Ionian Basin (Lefkas Island, western Greece) as compared to the Umbria-Marchean Basin (Central Italy). Boll. Serv. Geol. Ital. 114, 97-158.

Podlaha, O.G., Mutterlose, J., Veizer, J., 1998. Preservation of $\delta^{18} \mathrm{O}$ and $\delta^{13} \mathrm{C}$ in belemnite rostra from the Jurassic/early Cretaceous successions. A. J. Sc. 298, 324-347.

Quesada, S., Robles, S., Rosales, I., 2005. Depositional architecture and transgressive-regressive cycles within Liassic backstepping carbonate ramps in the Basque-Cantabrian Basin, northem Spain. J. Geol. Soc. Lond. 162, 531-548.

Raup, D.M., Sepkoski Jr., J.J., 1988. Testing for periodicity of extinction. Science 241, 94-96.

Riegraf, W., 1982. The bituminous Lower Toarcian at the Truc de Balduc near Mende (Département de la Lozère, S-France). In: Einsele, S., Seilacher, A. (Eds.), Cyclic and Event Stratification. Springer, New York, pp. 506-511.

Röhl, H.J., Schmid-Röhl, A., Oschmann, W., Frimmel, A., Schwark, L., 2001. The Posidonia Shale (Lower Toarcian) of SW-Germany: an oxygen-depleted ecosystem controlled by sea level and palaeoclimate. Palaeogeogr. Palaeoclimatol. Palaeoecol. 165, 27-52.

Rosales, I., Robles, S., Quesada, S., 2001a. Registro de la composición isotópica del Jurásico inferior de la Cuenca Vascocantábrica: metodología analítica y relación con los depósitos orgánicos. Geotemas 3, 61-64.

Rosales, I., Quesada, S., Robles, S., 2001b. Primary and diagenetic isotopic signals in fossils and hemipelagic carbonates: the Lower Jurassic of northern Spain. Sedimentology 48, 1149-1169.

Rosales, I., Robles, S., Quesada, S., 2003. Determinación de las variaciones de la temperatura del agua marina en el Lías en la Cuenca Vasco-Cantábrica mediante la utilización de parámetros geoquímicos $\left(\delta^{18} \mathrm{O}, \mathrm{Mg} / \mathrm{Ca}, \mathrm{Sr} / \mathrm{Ca}\right)$. Geogaceta $34,79-82$.

Rosales, I., Quesada, S., Robles, S., 2004. Paleotemperature variations of Early Jurassic seawater recorded in geochemical trends of belemnites from the Basque-Cantabrian basin, northem Spain. Palaeogeogr. Palaeoclimatol. Palaeoecol. 203, 253-275.

Ruban, D.A., Tyszka, J., 2005. Diversity dynamics and mass extinction of the Early-Middle Jurassic foraminifers: a record from the Northwestern Caucasus. Palaeogeogr. Palaeoclimatol. Palaeoecol. 222, 329-343.

Ruget, C., 1985. Les Foraminifères (Nodosariidés) du Lias de l'Europe occidentale. Doc. Lab. Géol. Lyon 94, 1-272.

Ruget, C., Cubaynes, R., Boutakiout, M., 1988. Première tentative de biozonation du Toarcien moyen (zones à Bifrons et à Variabilis) du Sud Quercy, par les foraminifères benthiques. Rev. de Paléobiologie, vol. spéc. 2, Benthos'86, pp. 203-207.

Sælen, G., 1989. Diagenesis and construction of the belemnite rostrum. Palaeontology 32, 765-798.

Sælen, G., Karstang, T.V., 1988. Chemical signatures of belemnites. N. Jb. Geol. Paläont. Abh. 177, 333-346.

Sælen, G., Doyle, P., Talbot, M.R., 1996. Stable-isotope analyses of belemnite rostra from the Whitby Mudstone F m., England: surface 
water conditions during deposition of a marine black shale. Palaios 11, 97-117.

Sælen, G., Tyson, R.V., Talbot, M.R., Telnæs, N., 1998. Evidence of recycling isotopically light $\mathrm{CO}_{2(\mathrm{aq})}$ in stratified black shale basins: contrasts between the Whitby Mudstone and Kimmeridge Clay formations, United Kingdom. Geology 26, 747-750.

Sælen, G., Tyson, R.V., Telnæs, N., Talbot, M.R., 2000. Contrasting watermass conditions during deposition of the Whitby Mudstone (Lower Jurassic) and Kimmeridge Clay (Upper Jurassic) formations, UK. Palaeogeogr. Palaeoclimatol. Palaeoecol. 163, 163-196.

Sass, E., Bein, A., Almogi-Labin, A., 1991. Oxygen-isotope composition of diagenetic calcite in organic-rich rocks: evidence for ${ }^{18} \mathrm{O}$ depletion in marine anaerobic pore water. Geology 19, 839-842.

Schmid-Röhl, A., Röhl, H.J., Oschmann, W., Frimmel, A., Schwark, L., 2002. Palaeoenvironmental reconstruction of Lower Toarcian epicontinental black shales (Posidonia Shale, SW Germany): global versus regional control. Geobios 35, 13-20.

Schouten, S., van Kaam-Peters, H.M.E., Rijpstra, W.I.C., Schoell, M., Sinninghe Damste, J.S., 2000. Effects on an oceanic anoxic event on the stable carbon isotopic composition of Early Toarcian carbon. Am. J. Sci. 300, 1-22.

Sepkoski Jr., J.J., 1989. Periodicity in extinction and the problem of catastrophism in the history of life. J. Geol. Soc. Lond. 146, 7-19.

Sepkoski Jr., J.J., 1996. Patterns of phanerozoic extinction: a perspective from global data bases. In: Walliser, O.H. (Ed.), Global Events and Event Stratigraphy in the Phanerozoic. Springer-Verlag, pp. 35-51.

Stampfli, G.M., Borel, G.D., 2004. The TRANSMED transects in space and time: constraints on the paleotectonic evolution of the mediterranean domain. In: Cavazza, W., Roure, F.M., Spakman, W., Stampfli, G.M., Ziegler, P.A. (Eds.), The IRANSMED AtlasThe Mediterraean Region from Crust to Mantle. Springer, Berlin, pp. 53-80. CD-ROM.

Suárez-Vega, L.C., 1974. Estratigrafía del Jurásico en Asturias. Cuad. Geol. Ibér. 3, 1-369.

Svensen, H., Jamtveit, B., Planke, S., Chevallier, L., 2006. Structure and evolution of hydrothermal vent complexes in the Karoo Basin, South Africa. Geol. Soc. Lond. J. 163, 671-682.

Svensen, H., Planke, S., Chevallier, L., Malthe-Sørensen, A., Corfu, F., Jamtveit, B., 2007. Hydrotermal venting of greenhouse gases triggering Early Jurassic global warming. Earth Planet. Sci. Lett. 256, 554-566.

Tissot, B., Califet-Debyser, Y., Deroo, G., Oudin, J.L., 1971. Origin and evolution of hydrocarbons in Early Toarcian Shales, Paris Basin, France. AAPG Bull. 55, 2177-2193.

Tremolada, F., van de Schootbrugge, B., Erba, E., 2005. Early Jurassic schizosphaerellid crisis in Cantabria, Spain: implications for calcification rates and phytoplankton evolution across the Toarcian oceanic anoxic event. Paleoceanography 20, PA211. doi:10.1029/ 2004PA001120.

Valenzuela, M., 1988. Estratigrafía, sedimentología y paleogeografia del Jurásico de Asturias. Ph D. Thesis, Depto. Geología Univ. Oviedo, Spain.

van Breuguel, Y., Baas, M., Schouten, S., Mattioli, E., Sinnighe Damsté, J.S., 2006. Isorenieratane record in black shales from the Paris Basin, France: constrains on recycling of respired $\mathrm{CO}_{2}$ as a mechanism for negative carbon isotope shifts during the Toarcian oceanic anoxic event. Paleoceanography 21, PA4220. doi:10.1029/ $2006 \mathrm{PA} 001305$.

van de Schootbrugge, B., McArthur, J.M., Bailey, T.R., Rosenthal, Y., Wright, J.D., Miller, K.G., 2005a. Toarcian oceanic anoxic event: an assessment of global causes using belemnite $\mathrm{C}$ isotope records. Paleoceanography 20, PA3008. doi:10.1029/2004PA001102.

van de Schootbrugge, B., Bailey, T.R., Rosenthal, Y., Katz, M.E., Wright, J.D., Feist-Burkhardt, S., Miller, K.G., Falkowski, P.G., $2005 \mathrm{~b}$. Early Jurassic climate change and the radiation of organicwalled phytoplankton in the Tethys ocean. Paleobiology 31, 73-97.

Vera, J.A., 2001. Evolution of the South Iberian Continental margin. In: Ziegler, P.A., Cavazza, W., Robertson, A.H.F., CrasquinSoleau, S. (Eds.), Pery-Tethys Memoir 6: Peri-Thetyan Rift/ Wrench Basins and Passive Margins. Mém. Mus. Natl. Hist. Nat., vol. 186 , pp. 109-143.

Vörös, A., 2002. Victims of the Early Toarcian anoxic event: the radiation and extinction of Jurassic Koninckinidae (Brachiopoda). Lethaia 35, 345-357.

Walliser, O.H., 1996. Patterns and causes of global events. In: Walliser, O.H. (Ed.), Global Events and Event Stratigraphy in the Phanerozoic. Springer-Verlag, pp. 7-19.

Wignall, P.B., 2001. Large igneous provinces and mass extinctions. Earth-Sci. Rev. 53, 1-33.

Wignall, P.B., Newton, R.J., Little, C.T.S., 2005. The timing of paleoenvironmental change and cause-and-effect relationships during the early Jurassic mass extinction in Europe. Am. J. Sci. 305, 1014-1032.

Wignall, P.B., McArthur, J.M., Little, C.T., Hallam, A., 2006. Methane release in the Early Jurassic period. Nature 441, E5 Comments to Kemp et al., 2005.

Wright, E.K., 1987. Stratification and paleocirculation of the Late Cretaceous Western Interior Seaway of North America. Geol. Soc. Amer. Bull. 99, 480-490.

Ziegler, P.A., 1990. Geological Atlas of Western and Central Europe, 2nd edition. Shell Internationale Petroleum Maatschappij, The Hague. 